University of California, Hastings College of the Law UC Hastings Scholarship Repository

Faculty Scholarship

$1-1-2015$

\title{
After Amnesties are Gone: Latin American National Courts and the New Contours of the Fight Against Impunity
}

Naomi Roht-Arriaza

UC Hastings College of the Law, rohtarri@uchastings.edu

Follow this and additional works at: https://repository.uchastings.edu/faculty_scholarship

\section{Recommended Citation}

Naomi Roht-Arriaza, After Amnesties are Gone: Latin American National Courts and the New Contours of the Fight Against Impunity, 37 Hum. Rts. Q. 341 (2015).

Available at: https://repository.uchastings.edu/faculty_scholarship/1300

This Article is brought to you for free and open access by UC Hastings Scholarship Repository. It has been accepted for inclusion in Faculty Scholarship by an authorized administrator of UC Hastings Scholarship Repository. For more information, please contact wangangela@uchastings.edu. 
University of California, Hastings College of Law

From the SelectedWorks of Naomi Roht-Arriaza

2015

After Amnesties are Gone: Latin American National Courts and the New Contours of the Fight Against Impunity

Naomi Roht-Arriaza 


\title{
After Amnesties are Gone: Latin American National Courts and the new Contours of the Fight Against Impunity
}

\author{
Naomi Roht-Arriaza*
}

\begin{abstract}
Latin America is the one region that, in the wake of massive and systematic violations of human rights, has made inroads into trying such crimes in national courts. After decades in which cases were dismissed on grounds of amnesty, statutes of limitations, or other impediments to trial, these barriers have fallen in a majority of countries. This turnaround - while fragile and incomplete-is remarkable. It provides important and inspirational lessons for lawyers, judges, and advocates in other regions, and for international justice efforts. Cases involving international crimes in the courts of Latin American countries have experienced distinct phases. In the first phase, advocates confronted barriers to bringing the cases into court at all. In the second and current phase, courts are facing the challenges of organizing trials that involve hundreds of defendants and victims, or using the elements of crimes like genocide to show overall patterns of atrocity. A final, emerging phase shifts the focus from trial to punishment. This phase has led to creative-and controversial—propositions about reduced sentences, suspended sentences, and alternatives to imprisonment in cases involving international crimes.
\end{abstract}

\footnotetext{
* Naomi Roht-Arriaza is Distinguished Professor of Law at the University of California, Hastings College of the Law in San Francisco. Professor Roht-Arriaza is the author of The Pinochet Effect: Transnational Justice in the Age of Human Rights (2005) and Impunity and Human Rights in International Law and Practice (1995). She is coeditor of Transitional Justice in the Twenty-First Century: Beyond Truth versus Justice (2006). She is a coauthor of The International Legal System: Cases and Materials (Foundation Press 2010) and of numerous articles on accountability for international crimes, reparations, and transitional justice. In 2011 she was a Democracy Fellow at the US Agency for International Development, and in 2012 she was a Senior Fulbright Scholar in Botswana. She is the president of the Board of the Due Process of Law Foundation and a legal advisor to the Center for Justice and Accountability. Professor Roht-Arriaza thanks Sarah Londer for excellent research assistance.
} 


\section{INTRODUCTION: THREE SNAPSHOTS}

On the morning of 28 November 2012, the courtroom was standing room only. On one side were the two official prosecutors, representing the State, and two lawyers representing the Human Rights Secretariat, along with seven attorneys representing groups of victims. On the other side were over twenty lawyers — both public defenders and private counsel-representing sixty-eight defendants, all accused of illicit detention, torture, homicide, (including "death flights") and other crimes against humanity committed in the Naval Mechanics' School (ESMA) clandestine detention center in Buenos Aires, Argentina from 1976 to 1978. As the three judges read out the charges and settled in to hear over 900 witnesses, other trials were underway in almost every province of Argentina. Altogether, over 2,000 cases had been opened by 2013, arising from the years of state terrorism. The country was determined to try every one of those responsible.

A few months later, on 19 March 2013, another Latin American courtroom was also full to overflowing. For the first time, a former head of state was on trial for genocide in the courts of his own country. The country was Guatemala, and the former dictator was Efrain Rios Montt, who had taken power in a March 1982 coup and presided over the worst atrocities in the country's recent history. He was charged, along with his intelligence chief, with the deaths of some 1,771 Ixil Maya civilians, and the rape, torture, or forced displacement of nearly 30,000 more, during 1982 and 1983. Representatives of the victims filled the courtroom, many of them with headphones as they listened to the translation from Spanish to their native Ixil.

And a few months after that, on 25 July 2013, yet another full courtroom listened to Colombian president Juan Manuel Santos deliver a spirited defense of his country's draft Legal Framework for Peace before the Constitutional Court. The law, which would allow a policy of selective prosecutions and limited punishment of those who committed crimes in the context of Colombia's protracted civil war, was, he said, necessary to successfully conclude peace talks with insurgents. The complainants, representing a human rights $\mathrm{NGO}$, argued that institutionalizing prosecutions of only a few would result in large-scale impunity and thus violate national and international law. Both sides agreed that a blanket amnesty for those committing crimes against humanity was legally and politically unacceptable. The Constitutional Court was asked to rule on other alternatives.

Latin America is the one region that-in the wake of massive and systematic violations of human rights and international crimes like genocide, crimes against humanity, and war crimes - has made inroads into prosecuting such crimes in national courts. Courts in a significant number of Latin American countries have prosecuted officials for killings, forced disappearances, 
torture, and other acts that constitute international crimes. ${ }^{1}$ The number of indictments and trials is impressive: According to statistics from 2012, over 2,000 people have been or are on trial in Argentina for the crimes discussed here; 370 have been found guilty, although only a few have exhausted their appeals. $^{2}$ In Chile, 1,342 people are being or have been tried for crimes arising from acts committed during the dictatorship. This number represents cases involving 75 percent of the victims of summary execution or forced disappearance, but only a small percentage of those potential cases involving torture or arbitrary detention. Some 260 people have been found guilty, of whom seventy-five are now serving time in prison. ${ }^{3}$ In Peru, as of 2012, sixty-six people have been found guilty in human rights-related trials, while 121 have been acquitted. ${ }^{4}$ Across the region, convictions include five former heads of state and a number of high-ranking military, police, and civilian officials. ${ }^{5}$

This turnaround comes after decades in which cases were dismissed on grounds of amnesty, statutes of limitations, or other impediments to trial. Although the change is still fragile and incomplete, it is remarkable. It provides important and inspirational lessons on the ability of civil society networks - especially family members, human rights advocates, and the professionals allied with them-to change law, policy, and political consensus through creativity and perseverance. It also demonstrates that the expedient of amnesty, widely discussed during the "peace-versus-justice" debates of

1. Professor Ximena Medellín Urquiaga has compiled many of these judgments into two volumes; the Digest is available in English and Spanish online at http://www.dplf.org. See 1 Ximena Medellin Urquiaga, Digest of Latin American Jurisprudence on International Crimes, Due Process of Law Foundation (2010), available at http://www.dplf.org/sites/ default/files/1271715939_0.pdf; 2 Ximena Medellin Urquiaga, Digest of Latin American Jurisprudence on International Crimes, Due Process of Law Foundation (María Clara Galvis Patiño ed., 2013), available at http://www.dplf.org/sites/default/files/digesto_jurisprudencia_en_pdf_0.pdf. A third volume, on victims' rights, is in progress.

2. Situación de los Juicios por Crímenes de Lesa Humanidad en la Argentina, CENTRO DE Estudios Legales y SOCIAlES, 21 Mar. 2013, available at http://www.cels.org.ar/comunicacion/ index.php?info $=$ detalleDoc\&ids $=4 \&$ lang $=$ es\&ss $=46 \& i d c=1605$ (stating that, as of March 2013, 2,071 persons had been accused of crimes relating to state terrorism, and 370 had been convicted); Largest Trial of "Dirty War" Crimes Starts in Argentina, BBC, 28 Nov. 2012, available at http://www.bbc.com/news/world-latin-america-20523955.

3. Derechos Humanos en Argentina: Informe 2013, Centro de Estudios Legales y Sociales 98-100 (2013), available at http://www.cels.org.ar/common/documentos/CELS.\%20 Informe\%202013\%20[completo].pdf; Violaciones Masivas, Sistemáticas e Institucionalizadas en el Período 1973-1990, Instituto Nacional Derechos Humanos 286 (2014), available at http://www.indh.cl/wp-content/uploads/2014/12/Violaciones-masivassistemáticas-e-institucionalizadas-en-el-per\%C3\%ADodo-1973-1990-INDH-2014-.pdf.

4. Id. at 126 .

5. The five are: Peru's Alberto Fujimori, Argentina's Jorge Videla, Bolivia's Luis Garcia Meza, Uruguay's Juan Bordaberry, and Guatemala's Efrain Rios Montt (later annulled on procedural grounds, see below). Augusto Pinochet of Chile died while indicted and awaiting trial. For trends generally on trying heads of state, see Prosecuting HeAds of State (Ellen L. Lutz \& Caitlin Reiger eds., 2009). 
the last few years, ${ }^{6}$ can be of limited effectiveness over time. The goal of this article is not to rehash those debates, but to ask what happens if national courts and prosecutors take seriously the prohibition on blanket amnesties. Even if the evidence worldwide is more ambiguous, ${ }^{7}$ a rejection of amnesty seems to be the overwhelming trend in this region.

This rejection of amnesty raises the question: What now? What do courts, legislatures, leaders, and advocates do once amnesty for international crimes is no longer an option? How do they manage to actually prosecute the hundreds, if not thousands, of potential cases? I find that efforts to conduct manageable and fair trials come in several variants: consolidating cases into large "mega-trials," or using the international crime definitions to structure a few trials that show the overall patterns of atrocity. But, in addition to those strategies, ruling out the amnesty option has another result: it leads courts and legislatures to turn to post-conviction variations in sentencing and in prison conditions. While outright pardons have been disfavored, reduced or suspended sentences, lenient conditions of confinement, and other types of "alternative sentences" have become more prevalent in the region.

The lessons learned on overcoming impediments to prosecution after atrocities, organizing trials after systematic and massive crimes are committed, and negotiating peace in the absence of an amnesty option, will be useful for advocates working toward national prosecutions for violations of human rights and the laws of war in Africa, Asia, and elsewhere. The experiences of Latin American countries will also prove vital as efforts at international justice turn back to improving national capacity after a tempering of early enthusiasm for building global institutions. The ad hoc Tribunals are closing; the existing hybrid or mixed courts, like those of Sierra Leone or Cambodia, are finished or are in the process of finishing; and the International Criminal Court (ICC) is subject to increasing criticism for being slow, inefficient, and politically clumsy. It is clearer than ever that if the fight against impunity is to progress, it will have to be largely-although not exclusively-through national efforts. This revelation has motivated new interest in "positive complementarity," and in the work of national courts. Yet, there is little work in the English language that analyzes the regional experience as a whole, its evolution, achievements and challenges, and its emerging directions. This article fills that void.

6. See, e.g., Amnesty in the Age of Human Rights Accountability: Comparative and International Perspectives (Francesca Lessa \& Leigh A. Payne eds., 2012); Mark Freeman, Necessary Evils: Amnesties and the Search for Justice (2009); Transitional Justice Inst., Univ. of Ulster, The Belfast Guidelines on Amnesty and Accountability (2013), available at http://eprints.ulster. ac.uk/28262/1/Belfast_Guidelines_on_Amnesty_and_Accountability_Report.pdf.

7. See louise Mallinder, Amnesty, Human Rights and Political Transitions: Bridging the Peace and Justice Divide (2008). 
Cases involving international crimes in the courts of Latin American countries have gone through distinct phases. These phases are analytical rather than chronological and overlap both within, and among, countries. In the first phase, advocates confronted barriers to bringing the cases into court at all. Amnesty laws, statutes of limitation, and non-incorporation of international crimes into domestic penal codes made it difficult and timeconsuming to get cases into court. These "first generation" issues have now been resolved for the most part, although there are exceptions and outliers. For most courts in the region, amnesties are unlawful, for reasons detailed below. For a minority of courts, in contrast, while amnesties might currently violate international law, they did not at the time they were instituted; so, in the view of these courts, it would violate principles of legality to rescind an existing legal benefit. Thus, these courts uphold amnesties, not principally because of their contribution to peace, but in order to avoid overturning settled expectations.

The second phase has focused on actually prosecuting the cases. The new issues involved range from trying increasingly complex and sensitive kinds of crimes, to organizing trials involving multiple defendants and victims, to reaching behind the triggermen and arriving at the high-ranking military and civilian officials, as well as the financial and political figures who were complicit in the crimes. These efforts could only be instigated decades after the crimes-a reality that has created challenges for aging witnesses, victims, and defendants. While the first generation of issues presents rich lessons for other countries now urging their national courts to take up cases involving international crimes, the second generation can illuminate some of the knotty problems currently facing international justice efforts, especially as concerns trial organization and victim participation.

A final set of cases, arising from post-conviction dilemmas-as well as from the region's only ongoing armed conflict in Colombia-starkly poses the problem of negotiating peace deals within the permissible limits on amnesty, and again has led to creative-and controversial-propositions about alternatives to imprisonment and the role of sentencing in international crimes. These discussions, in particular, may open the space for thinking about similar issues elsewhere.

The article proceeds as follows. Part II provides historical background. Part III outlines the first phase of Latin American prosecutions, highlighting initial obstacles to adjudication that are common to many of these cases-most prominently issues of amnesty and statutes of limitations. It draws out the lessons of that phase for national prosecutions elsewhere. Part IV discusses the innovations of the current phase, especially with regard to the organization of trials involving many defendants and victims. It also explores some of the innovative jurisprudential contributions of the region in the trial phase. Part $\mathrm{V}$ looks at current efforts, especially in Colombia, to limit prosecutions consistent with international standards. Part VI draws conclusions. 


\section{REPRESSION AND TRANSITION}

While generalizations are always dangerous, there are a few commonalities about the crimes committed, and the responses to them, that make it possible to speak of regional trends. During the 1970s and 1980s, actions carried out largely_although not exclusively_by security forces led to massive crimes, including murder, forced disappearance, ${ }^{8}$ torture, massacre, arbitrary detention, kidnapping of children, and other acts, largely aimed at real or perceived political opponents. During that period, the courts-with a few exceptions-could not or did not play a rights-protective role. The jurisprudence of that time indicates that courts routinely denied habeas corpus requests and played a passive role with respect to the political branches of government, or were complicit in violations. ${ }^{9}$

Eventually, civilian governments came to power, either as a result of military disgrace or pre-arranged transitions, or after UN-sponsored peace agreements. These governments were slow to adopt measures to investigate or prosecute the crimes. The 1985 Trial of the Juntas in Argentina established the existence of a systematic plan to imprison, torture, and kill political opponents; members of the ruling military juntas were sentenced to life in prison. That trial and the subsequent trial of Bolivian dictator Luis García Meza were notable exceptions, but for the most part, governments eschewed prosecutions and retained_or put in place_amnesty laws that precluded investigation and prosecution of the security forces. ${ }^{10}$ Even in Argentina, after the trials of the Junta leaders, the government pushed through laws limiting prosecutions and later pardoned even those leaders who had been convicted in the Junta trials. Similar laws existed in Uruguay, Chile, Peru, Nicaragua, El Salvador, Guatemala, and Brazil. The amnesties were triggered in part by a fear of military backlash, and in part because the transitions were often

8. A forced disappearance is defined as "the arrest, detention, abduction or any other form of deprivation of liberty by agents of the state or by persons or groups of persons acting with the authorization, support or acquiescence of the state, followed by a refusal to acknowledge the deprivation of liberty or by concealment of the fate or whereabouts of the disappeared person, which place such a person outside the protection of the law." International Convention for the Protection of All Persons from Enforced Disappearance, adopted 20 Dec. 2006, G.A. Res. A/RES/61/177, U.N. GAOR, 61st Sess., art. 2, U.N. Doc. A/61/448 (2006) 2716 U.N.T.S. 3 (entered into force 23 Dec. 2010).

9. William C. Prillaman, The Judiciary and Democratic Decay in Latin America: Declining Confidence IN THE Rule of Law 153, 10 (2010) (explaining, "Between 1973 and 1983, for example, the Chilean Supreme Court denied more than 4,000 habeas corpus requests - more than 98 percent of all such petitions.").

10. See Brian Loveman, "Protected Democracies" and Military Guardianship: Political Transitions in Latin America, 1978-1993, 36 J. Inter-Am. Stud. \& World Aff. 105, 118, 120 (1994). See also Daniel Mattes, Nunca Más: Trials and Judicial Capacity in PostTransitional Argentina (May 2012) (unpublished thesis, Center for Democracy, Development, and the Rule of Law, Stanford University) (discussing "The Trial of the Juntas"), available at http://cddrl.fsi.stanford.edu/sites/default/files/DANIEL_MATTES.pdf. 
deals between elites and the military high command-essentially a return to the barracks in exchange for total impunity. In those countries without formal amnesty laws, a combination of other legal obstacles in addition to an inhospitable political and security climate, made judicial action against past human rights violators rare.

This panorama has changed. Multiple factors explain the shift over the last decade away from amnesties and toward prosecutions. Perhaps the most important was the persistent debate within each country about the need to (re)establish the rule of law for everyone. Family members of the disappeared, journalists, lawyers, and human rights groups all played important roles over decades to document the cases, push judges to assume their role as protectors of rights, and change the political and legal conditions that impeded the ability to prosecute. Even in the most difficult moments, these actors never stopped demanding justice before local courts, traveling to international forums to seek support, and publicizing a reality that many people would rather have ignored or forgotten. The evidence they managed to obtain and the habeas corpus petitions they filed — even though denied at the time-were useful in providing proof of the events and, many years later, became the starting point in the work of investigators and judges. Their role as private prosecutors was indispensable in forcing prosecutors and judges to push ahead. ${ }^{11}$

There were additional factors at work. New governments based their legitimacy in part on their distinction from, and opposition to, the old regime. In Argentina, reopening and expanding trials became a government project after 2003, but this was not true elsewhere in the region. However, where incoming governments were opposed to trials, they still supported the idea of truth, even in the absence of full justice. The first initiative in this direction was the creation of investigative, or "truth," commissions; these commissions were acceptable even when elite pacts or negotiated settlements excluded the possibility of trials. These commissions played an important role in gathering information, establishing overall patterns of violations, combatting official denials, and making the large number of victims visible to the whole society. They became an important venue for victims to be heard and recognized, which was essential to creating or reinforcing their determination to bring cases before the courts. The information they gathered was passed on to the prosecuting authorities, although prosecutors took a long time to act.

11. In many civil law systems, victims of crimes can act as private or auxiliary prosecutors in criminal cases. Once the defendant has been found guilty, the victim/complainants can ask the court for civil damages. Vivienne O'Connor, Practitioner's Guide: Common Law and Civil Law Traditions, Int'L Network to Promote the Rule of Law (INPROL) 21 (2012), available at http://inprol.org/sites/default/files/publications/2012/common_law_ civil_law_pg_final.pdf. 
In many countries, judicial reforms brought in new judges with more training and interest in international law, as well as in the rights-protective role of judges. New specialized chambers, revised criminal procedure codes, and-in some cases - changes to constitutions themselves created a more hospitable climate for trials. In Argentina, for example, a 1994 legal reform gave human rights treaties constitutional status; Colombia's 1991 constitution granted treaties primacy over conflicting domestic law. ${ }^{12}$

These internal factors were intertwined with external ones. The long process of human rights codification began to bear fruit in the 1980s, when the major treaties finally entered into force. The post-armed conflict or postdictatorship governments acceded, as some of their first acts, to the corpus of human rights treaties. In particular, most countries in the region became parties to the American Convention on Human Rights, and the Inter-American Court of Human Rights began to operate.

In its first adversarial case, the Inter-American Court established the obligation of States to investigate, prosecute, punish, and repair grave human rights violations as a bedrock principle. ${ }^{13}$ Since then, in its jurisprudence on forced disappearances, summary executions, torture, and on the importance of respecting and ensuring the rights of victims, the Inter-American Court has set the standard followed by many judges in the region. Of particular relevance were the decisions in the cases of Barrios Altos (Peru) and Almonacid Arrellano (Chile), in which the Court held that amnesties and other limiting devices like statutes of limitations could not override the state's duty to investigate, prosecute, and punish those responsible, and to provide reparation to victims. ${ }^{14}$ The Inter-American jurisprudence on the subject broadened over time to include not only self-amnesties decreed by repressive regimes to cover their own crimes, but also amnesties put into place by successor regimes and those that emerged from peace accords; prohibitions extended to statutes of limitation as well, and to any other device limiting access of victims to information and justice. Even where the underlying crimes took place before the state was a party to the Convention and so could not be

12. Constitución de la Nación Argentina [Constitution], 22 Aug. 1994, art. 75; Constitución Política de la República de Colombia de 1991 [Constitution], 6 July 1991, art. 93.

13. Velásquez-Rodríguez v. Honduras, Judgment, Inter-Am. Ct. H.R. (ser. C) No. 4, ฯ 166 (29 July 1988).

14. Barrios Altos v. Peru, Judgment, Inter-Am. Ct. H.R. (ser. C) No. 87, I 3 (30 Nov. 2001); Almonacid-Arellano et al. v. Chile, Judgment, Inter-Am. Ct. H.R. (ser. C) No. 154, I 22 (26 Sept. 2006). Other important cases on the subject deal with amnesties in Brazil, Uruguay, and El Salvador. See Gomes Lund et al. ("Guerrilha do Araguaia") v. Brazil, Judgment, Inter-Am. Ct. H.R. (ser. C) No. 219 (26 Sept. 2006); Gelman v. Uruguay, Judgment, Inter-Am. Ct. H.R. (ser. C) No. 221 (24 Feb. 2011); Massacres of El Mozote and Neighboring Locations v. El Salvador, Judgment, Inter-Am. Ct. H.R. (ser. C) No. 252 (25 Oct. 2012). 
adjudicated under the Convention, the Court held that amnesties or other impediments interfered with victims' current rights to remedy and to their day in court. ${ }^{15}$ National courts widely cited the Court's decisions in this arena.

Decisions on the right to truth, and on the broad scope of remedies, have also been important for national judges. Along with the Court, the Inter-American Commission on Human Rights has consistently encouraged governments to combat impunity more effectively by using public hearings, reports, periodic meetings with justice sector officials, and capacity-building efforts toward that end. The role of the Commission in the negotiation of friendly settlements has demonstrated to governments that improving the quality of national justice systems may help them avoid defending large numbers of cases before the Inter-American system and ultimately paying costly reparations when they lose. ${ }^{16}$

Another factor that helped change the regional panorama was the 1998 arrest of former Chilean dictator Augusto Pinochet. ${ }^{17}$ The arrest warrant was issued by a Spanish judge, Baltazar Garzón, for the crimes of genocide, terrorism, and torture committed against Spanish and Chilean citizens. Spain's universal jurisdiction statute at the time covered a handful of particularly grave international crimes, even when neither the accused nor the victim was a Spanish citizen. As is now well known, Pinochet decided to travel to the United Kingdom and was arrested in London. During the extradition hearings, the British House of Lords twice approved his extradition to Spain on charges of torture and conspiracy to torture. After more than a year under house arrest, Pinochet was returned to Chile, ostensibly because of his health problems. There, he remained under multiple indictments until his death. The Pinochet case was widely known in Latin America and contributed to changing the views of lawyers, judges, activists, and state officials on the possibilities of international justice. If someone as powerful as Pinochet could face justice, what about the others who had also ordered murders and disappearances? And if Spanish and British courts thought that the accusations of torture and disappearance were credible and could be prosecuted even against a former head of state, many years after their occurrence, why could local courts not begin to investigate and prosecute their own nationals accused of similar atrocities? Other universal jurisdiction cases involved defendants from Argentina, Uruguay, El Salvador, and Guatemala.

15. That is, they violated American Convention on Human Rights, signed 22 Nov. 1969, arts. 8, 25, O.A.S. Doc. OEA/Ser.L/V/II.23, doc. 21, rev. 6 (1979), O.A.S.T.S. No. 36, 1144 U.N.T.S. 143 (entered into force 18 July 1978), even if the Court could not reach the underlying killings, disappearances, or torture.

16. Jo M. Pasqualucci, The Practice and Procedure of the Inter-American Court of Human Rights 147-49 (2d ed. 2012).

17. See generally Naomi Roht-Arriaza, The Pinochet Effect: Transnational Justice in the Age of Human Rights (2005). 
The approval of the Rome Statute and the establishment of the ICC in 1998 also strengthened the voices pushing for prosecutions. The essence of the Statute, unlike the prior tribunals created by the UN Security Council, is that international jurisdiction should be a backstop to national jurisdiction; the Court can act only when national courts are unable or unwilling to do so. ${ }^{18}$ This means that states parties to the ICC should modify their internal law to make sure they can prosecute the crimes listed in the Statute. The ICC does not have jurisdiction over crimes committed before 2002, and thus will not be able to investigate past crimes from the region-with the prominent exception of Colombia's ongoing conflict. However, the process of the Court's formation and development created a space for dialogue among legal professionals and other stakeholders regarding the need for justice for the worst international crimes. Latin Americans played an important role in the negotiations and formation of the Court, and almost all states in the region are parties to the Rome Statute.

These background conditions help explain the shift from non-prosecution to prosecution as the dominant norm in the region. The discussion turns now to the legal issues involved.

\section{THE FIRST PHASE OF PROSECUTIONS}

\section{A. Amnesties and Statutes of Limitations}

The first issue confronting advocates and prosecutors in most countries was the existence of amnesties and other barriers that forbade even opening an investigation into human rights-related crimes. The amnesty laws in each country took a slightly different form. In Chile, a blanket amnesty protected security forces from prosecution for anything-except theft or rape-that occurred between 1973 and 1978, the period of worst repression. In Argentina, the law created a conclusive presumption that anyone under the rank of commander was following orders and therefore not liable, although the stealing of babies or property was not covered by that presumption. In Uruguay, the state renounced its ability to prosecute crimes committed by the military. In El Salvador, anyone involved in a political crime or a common crime with twenty or more participants before 1993 was granted amnesty. In a few countries, the law referred to political crimes and "related common crimes." 19 The common denominator was that these laws did not

18. Rome Statute of the International Criminal Court, adopted 17 July 1998, art. 17, U.N. Doc. A/CONF.183/9 (1998), 2187 U.N.T.S. 90 (entered into force 1 July 2002).

19. See, e.g., Decreto Legislativo No. 486, 20 Mar. 1993, Ley de Amnistia General para la Consolidación de la Paz [Law of General Amnesty for the Consolidation of Peace] DiARIO 
differentiate between offenses clearly amenable to amnesty, like sedition or carrying arms or false documents, and international crimes like genocide, crimes against humanity, or war crimes. ${ }^{20}$ Nor was the protection of these laws conditioned upon any particular action to be taken by the suspect.

The process of overcoming these amnesty laws went through several phases. Early direct challenges to amnesty laws were uniformly unsuccessful. The most common ground for dismissal was a variation on the political question doctrine: Amnesty laws had been passed by the legislature, and courts had no business intervening in legislative decisions regarding how to best reconcile the country. ${ }^{21}$ So advocates brought cases that were not covered by the laws. These included, for example, prosecutions for post-1978 summary executions in Chile, for crimes that occurred outside the country in Uruguay, and for baby stealing in Argentina.

In addition to seeking avenues where the law did not apply, advocates began working within the confines of the amnesty law itself, rather than directly challenging its legality. One variant of this strategy focused on enforced disappearances. ${ }^{22}$ In an enforced disappearance, by definition, the victim's body is never found. However, in most countries, a dead body is necessary for a charge of murder. Advocates therefore argue that the crime is permanent-or continues until the body appears. Without a body, the date of death is unknown and could well have occurred beyond the amnesty period, so the amnesty cannot be applied wherever it is time-limited. Where the date of death is uncertain, a statute of limitations also cannot apply because the statute never begins to run. Advocates continue to use this theory today in places where amnesties are still applied, such as Brazil. ${ }^{23}$

Another innovative legal strategy delayed the question of amnesty until the end of the trial process, so that initial investigations would not be foreclosed. Judges — especially in Chile and Honduras_-began allowing

Oficial 318(56), 22 Mar. 1993 (El Sal.) [hereinafter Law of General Amnesty]; Decreto Ley No. 2.191, 19 Apr. 1978, Diario Oficial No. 30.042 (Chile); Law No. 23.492, Ley de Punto Final [Full Stop Law] 23 Dec. 1986, Boletín Oficial, 29 Dec. 1986 (Arg.); Law No. 23.521, Ley de Obediencia Debida [Due Obedience Law] 4 June 1987, Boletín Oficial, 9 June 1987 (Arg.); Lei No. 6.683/1979, Lei de Anistia [Amnesty Law] 28 Aug. 1979 (Braz.); Ley No. 15.848, Ley de Caducidad de la Pretensión Punitiva del Estado [Law on the Expiration of the Punitive Claims of the State] 22 Dec. 1986, Diario Oficial No. 22295, 28 Dec. 1986 (Uru.).

20. There were exceptions. Guatemala's 1996 National Reconciliation Law exempts genocide, forced disappearances, torture, and other crimes that must be prosecuted under Guatemala's treaty obligations from the scope of amnesty. Decreto No. 145-1996, Ley de Reconciliación Nacional [Law of National Reconciliation] 27 Dec. 1996 (Guat.).

21. For a full discussion of these early cases, see Naomi Roht-Arriaza \& Lauren Gibson, The Developing Jurisprudence on Amnesty, 20 Hum. RTs. Q. 843 (1998).

22. See id. at 844 n.5. For reasons discussed below, disappearance cases are often charged as aggravated kidnapping.

23. See Press Release, Amnesty Int'l, Brazil: Long-Standing Military Crimes Challenged by Historic Prosecution (15 Mar. 2012), available at http://www.amnesty.org/en/formedia/press-releases/brazil-long-standing-military-crimes-challenged-historic-prosecution-2012-0. 
investigations to proceed based on the rationale that an amnesty law requires knowing exactly who is to be amnestied and for what crimes. Therefore, only after full investigation and trial could any amnesty apply. The strategy was limited, but it got cases into court.

A more direct attack on amnesty laws eventually came from judges who found that the laws violated the state's international obligations. In Argentina, Uruguay, and Peru, the result was to invalidate the amnesty laws. These types of decisions required two steps: first showing that the amnesties violated international law, and then explaining how that international law violation translated into a violation of binding obligations in domestic law. For example, Argentina reformed its Constitution in 1994 to give international human rights obligations a status superior to domestic statutes; therefore, a violation of these obligations trumped the amnesty enacted by statute. The Argentine courts cited the Inter-American jurisprudence summarized above, as well as the criminalization of crimes against humanity since Nuremberg, to hold the amnesty law invalid because it conflicted with international, and therefore constitutional, obligations.

In contrast, judges simply sidestepped the amnesty in Chile by holding that it was valid, but that it had to be interpreted so as not to conflict with the state's international obligations. Chilean judges pointed to the prohibitions on murder and cruel treatment in Article 3 of the 1949 Geneva Conventions, as well as to the need to prosecute crimes against humanity, in order to interpret the amnesty to exclude these crimes. ${ }^{24}$ The Supreme Court of El Salvador, in a similar move, found that the amnesty law could not preclude prosecution in cases where fundamental human rights had been violated. ${ }^{25}$ Thus, they avoided invalidating legislative action, while fundamentally changing the nature of the law in practice.

24. Corte Suprema de Justicia [C.S.J.] [Supreme Court], 17 Nov. 2004, "Miguel Angel Sandoval," Case No. 517-04, Revista Gaceta Jurídica [R.G.J.] No. 272, p. 109 (Chile). The current Chilean government has said that it wants Congress to annul the amnesty law; two bills are pending that would "interpret" the law, and that would amend the constitution to prohibit amnesties and statutes of limitations for war crimes, crimes against humanity, and genocide. However, as of December 2014, it had not yet done so. Observatorio de Justicia Transicional, Universidad Diego Portales, Santiago de Chile, Boletín Informativo No. 27, Centro de Derechos Humanos 2-3 (Oct.-Nov. 2014), available at http://www.londres38.cl/1934/articles-96921_recurso_1.pdf; Chile to Repeal Amnesty Law, Buenos Aires Herald, 12 Sept. 2014, available at http://www.buenosairesherald.com/ article/169534/chile-to-repeal-amnesty-law.

25. Sala de lo Constitucional de la Corte Suprema de Justicia [Constitutional Chamber of the Supreme Court] 26 Sept. 2000, Application for Constitutional Review, 24-97/21-98 (El Sal.) (discussing the constitutionality of articles 1 and 4 of the Law of General Amnesty, which had granted "absolute and unconditional" amnesty to perpetrators, supra note 19 , and granting investigating judges the discretion to determine whether the amnesty law's application in a particular case would violate El Salvador's treaty obligations). Unfortunately, the Salvadoran Prosecutor's Office has until recently declined to take up the Court's invitation to classify crimes as involving fundamental rights. In 2013, the Prosecutor announced an investigation into an emblematic 1981 massacre at El Mozote. The Constitutional Chamber of the Salvadoran Supreme Court is currently considering again the constitutionality of the amnesty law, and may decide to annul or limit it. 
International law also supplied the foundational argument against dismissals based on statutes of limitations. In addition to the continuing crime argument that was raised in forced disappearance cases, courts found that crimes against humanity were imprescriptible. In some cases, they used the Convention on the Non-Applicability of Statutory Limitations to War Crimes and Crimes Against Humanity. In other cases, where the state was not a party to that treaty, the courts applied its principles as a matter of customary international law. In a few cases, courts held that, even though a statute of limitations applied, it was tolled during the period of time when the courts were not independent, or when the cases could not realistically be brought due to security concerns or the lack of a democratic government.

These preliminary issues tied into another: How should the crimes be characterized? Were they common crimes — such as murder, aggravated kidnapping, and the like- under existing penal codes, or international crimes? If the former, how could the courts then deal with the problems of statutes of limitations or amnesties, when those restrictions were only prohibited with respect to crimes against humanity and other international crimes? If, on the other hand, the acts were characterized as international crimes, how could the accused be tried-consistent with principles of legality and the prohibition on ex post facto law-for crimes that were not specifically defined in the local penal code at the time they were committed?

This conundrum gave rise to some creative lawyering. Several courts held that, even though the charged crimes were common crimes under the penal code, they met the requirements for-and therefore were simultaneouslycrimes against humanity, which rendered them not subject to amnesties or statutes of limitations. This "subsumption" of ordinary crimes was licit because, even though the international crimes were not part of the relevant penal code, they were crimes under customary international law at least as far back as 1945. ${ }^{26}$ Thus, in line with Article 15 of the International Covenant on Civil and Political Rights, there was no ex post facto application of the law, nor was there lack of notice to defendants as to what behavior was unacceptable. ${ }^{27}$

26. See, e.g., Corte Suprema de Justicia de la Nación [National Supreme Court of Justice] 24 Aug. 2004, "Arancibia Clavel, Enrique Lautaro s/homicidio calificado y asociación ilícita y otros / recurso de hecho," Causa No. 259, Expediente A. 533. XXXVIII., at 6, 25, 44, 72 (Arg.); Sala Penal de la Corte Suprema [Penal Chamber of the Supreme Court] 13 Dec. 2006, Caso Molco, Case No. 559-04, Estudios Constitucionales 540 (Chile).

27. International Covenant on Civil and Political Rights, adopted 16 Dec. 1966, G.A. Res. 2200 (XXI), U.N. GAOR, 21st Sess., art. 15, U.N. Doc. A/6316 (1966), 999 U.N.T.S. 171 (entered into force 23 Mar. 1976) states:

No one shall be held guilty of any criminal offence on account of any act or omission which did not constitute a criminal offence, under national or international law, at the time when it was committed. ... . Nothing in this article shall prejudice the trial and punishment of any person for any act or omission which, at the time when it was committed, was criminal according to the general principles of law recognized by the community of nations.

For an application, see Penal Judge 19th Court, 26 Mar. 2009, Jose Nino Gavazzo Pereira et al., Sentence 036, File 98-247/2006 (Uru.). For similar results in the European Court of Human Rights, see Kononov v. Latvia, App. No. 36376/04, Eur. Ct. H.R. (17 May 2010). 


\section{B. Upholding Amnesties}

The minority of Latin American courts, which have decided to maintain the amnesty laws in the face of an accumulation of contrary Inter-American system jurisprudence, have largely done so based on the principle of legality. The basic argument is that, even though amnesties might now be disfavored or prohibited under international law, they were not so disfavored at the time they were passed. Therefore, the settled expectations of defendants have to be analyzed from the vantage of the 1970s or 1980s, instead of by today's standards. Thus, it would be contrary to the ban on retrospective lawmaking to undo prior laws.

For example, the Brazilian Supreme Court upheld the country's amnesty law in April 2010. Unlike in other countries, the 1979 law was popular because it led to the release and indemnity of hundreds of political prisoners; the language was only subsequently read to apply to the crimes of security forces. When the amnesty law was challenged as violating Brazil's international obligations, the Supreme Court held, by a vote of 7-2, that the law was still valid as applied to perpetrators of human rights crimes during that country's long authoritarian rule. The Court pointed out that the Brazilian amnesty law had been a demand of civil society and had eased the transition from past authoritarianism to democracy. While the court acknowledged the existence of a current norm prohibiting amnesties for crimes against humanity, it argued that the norm emerged after 1979, and so could not be applied to the amnesty law. ${ }^{28}$ Despite this decision, prosecutors continue to investigate forced disappearance cases based on the aforementioned theory that they are continuing crimes and thus not affected by any time-limited amnesty. In addition, the December 2014 report of the Brazilian Truth Commission recommended annulling the amnesty law, adding to pressure to revisit the issue. ${ }^{29}$

The Uruguayan Supreme Court, on the other hand, has flip-flopped on the issue: In October 2009 and again in November 2010, the Court held that the central articles of the 1986 Uruguayan amnesty law, which had withdrawn the government's ability to bring cases involving crimes committed by the military before 1985, were unconstitutional because they violated the state's international obligations, as well as the separation of

28. Supremo Tribunal Federal [STF], 29 Apr. 2010, Ordem dos Advogados do Brasil por meio de Arguição de Descumprimento de Preceito Fundamental, No. 153/2008, ฯ 5. See also 2 Marcelo D. Torelly, Justiça de Transição e Estado Constitucional de Direito: Perspectiva Teórico-Comparativa e Análise do Caso Brasileiro 309-54 (2012).

29. Anthony Boadle \& Brian Winter, Brazil Dictatorship Probe Urges Prosecuting Military, Companies, Reuters, 10 Dec. 2014, available at http://www.reuters.com/article/2014/12/10/ us-brazil-rousseff-dicatorship-idUSKBN0JO20L20141210. 
powers principle. ${ }^{30}$ In the wake of that decision-in addition to a number of prosecutions of high-ranking military and civilian officials, including the former head of state and foreign minister-the Uruguayan legislature signaled its own support for prosecutions in 2011. It declared that no statute of limitations or other legal limit was applicable to crimes committed by the military between 1986 and 2011, and that these crimes constituted crimes against humanity according to Uruguay's human rights treaty obligations. ${ }^{31}$ The aim was to comply with an Inter-American court ruling and to support the trend toward more prosecutions, but the law had the opposite effect.

On 22 February 2013, the Supreme Court invalidated several articles of the 2011 law by a 4-1 vote. The Court rested the decision on a reading (that the same Court had earlier rejected) that the amnesty law had created settled expectations, and that to override those expectations would constitute ex post facto lawmaking. Moreover, the legislature had no power to declare that specific conduct ex ante constituted crimes against humanity. Therefore, those crimes were not exempt from application of the statute of limitations and had to be dismissed..$^{32}$

An interesting feature of these minority decisions is that they do not primarily rely on arguments about tradeoffs between justice and peace or reconciliation; indeed, many of them recognize that in today's world, amnesties for international crimes are invalid. ${ }^{33}$ Rather, concerns regarding the upset of earlier settled expectations, in addition to the rule of lenity - the principle that defendants get the benefit of legal changes-trigger these courts' decision to uphold amnesty laws. In contrast, the majority of courts embrace the view that the amnesty laws were void $a b$ initio because they violated prior customary international law obligations, and so could not ever create settled expectations for potential defendants.

30. The 2009 case was: Suprema Corte de Justicia [Supreme Court of Justice] 19 Oct. 2009, Case of Nibia Sabalsagaray, Sentencia No. 365/2009; the 2010 case was: Suprema Corte de Justicia [Supreme Court of Justice] 29 Oct. 2010, Organización de los Derechos Humanos, Sentencia No. 1525.

31. Ley No. 18.831, 27 Oct. 2011, Pretensión Punitiva del Estado [Punitive Claim of the State] Diario Oficial No. 28340, 1 Nov. 2011. See also Jo-Marie Burt \& Francesca Lessa, Recent Sentence by Uruguayan Supreme Court Obstructs Search for Truth and Justice, Wash. Office on Latin Am. (WOLA) (28 Feb. 2013), available at http://www.wola.org/ commentary/recent_sentence_by_uruguayan_supreme_court_obstructs_search_for_truth_ and_justice. The case is: Corte Suprema de la Nación [Supreme Court of the Nation] 22 Feb.2013, "Excepción de inconstitucionalidad arts. 1, 2 y 3 de la Ley No. 18.831," IUE 2-109971/2011 Sentencia No. 20.

32. The Spanish Supreme Court used similar arguments in rejecting a recent attempt to investigate Civil War-era crimes despite a 1977 amnesty. See Naomi Roht-Arriaza, The Spanish Civil War, Amnesty, and the Trials of Judge Garzón, 16 Am. Soc. INT'L Law (2012), available at http://www.asil.org/sites/default/files/insight120725.pdf.

33. This may be due in part to the Inter-American Court's rejection of this argument in the cases of Barrios Altos, Almonacid-Arrellano, Gomez Lund, Gelman, and El Mozote, among others. See supra note 14. 


\section{THE SECOND GENERATION}

\section{A. Modes of Liability}

Even once cases were admissible, a major evidentiary hurdle remained, which involved linking individuals at the top of a chain of command with the triggermen on the bottom. Many of the cases involved the direct responsibility of the perpetrator-such as the torturer and the detention camp guard. However, in other cases, the accused had formed part of a chain of command, either through ordering crimes, or through refusing to prevent crimes or punish perpetrators, despite the knowledge and ability to do so. These cases required a theory of responsibility capable of linking the high-level accused, who were never at the scenes of the crimes, to the commission of the prohibited acts. The Argentine courts especially developed the necessary evidence and theories to tie military commanders to the work of often secret "task forces" in charge of detaining, torturing, and disappearing prisoners. While the World War II-era trials had developed a theory of "command responsibility," ${ }^{34}$ the Latin American courts pioneered a slightly different approach. They relied in part on a theory of "perpetration by means of an organized apparatus of power" that linked decision makers to a fungible group of organized subordinates who carried out a preformed plan. The key to the theory is that the subordinates are interchangeable, and that, even if culpable and conscious, the subordinates were not pulling the strings. The Supreme Court of Peru-in its conviction of the leader of the Shining Path guerrillas and of the former Peruvian President Alberto Fujimori for crimes committed in the Barrios Altos, La Cantuta, and SIE Basements cases-extended this theory to the criminal responsibility of civilian leaders for the crimes of their subordinates. ${ }^{35}$ The theory, recognized in the Rome

34. For an explanation of command responsibility, see Guenael Mettraux, The Doctrine of Superior/Command Responsibility, The Peace and Justice Initiative, available at http://www. peaceandjusticeinitiative.org/implementation-resources/command-responsibility.

35. Primera Sala Penal Transitoria de la Corte Suprema de Justicia [First Criminal Chamber of the Supreme Court of Justice] 7 Apr. 2009, Barrios Altos, La Cantuta, and SIE Basements (Alberto Fujimori), Expediente A.V. 19-2001. The theory of co-perpetration by means of an organized apparatus was developed by Claude Roxin, a German criminal law scholar. See Kai Ambos, The Fujimori Judgment: A President's Responsibility for Crimes Against Humanity as Indirect Perpetrator by Virtue of an Organized Power Apparatus, 9 J. INT'L CRIM. Just. 137 (2011). For an Argentine version, see Tribunal Oral en lo Criminal Federal de La Plata [Federal Criminal Oral Court No. 1 of La Plata] 19 Sept. 2006, "Almeida, Domingo y otros s/ Inf. arts. 80, 139, 142,144, 146, 45, 54 y 55 del C.P.", Causa No. 2251/06. Unfortunately, despite the Fujimori judgment, lower courts in Peru have been reluctant to apply theories of indirect or command liability, which explains the high number of acquittals of military officers. See Marta Martínez, Peru's Painful Mirror: Ten Years After the Final Report, Peruvians Reflect on the Impact of the Truth and Reconciliation Commission, INT'L CTR. TRANSITIONAL Justice (2013), available at http://www.ictj.org/perus-painful-mirror/. 
Statute, is becoming one of the predominant modes of liability in international criminal law. ${ }^{36}$

\section{B. Consolidating Trials: The Mega-Trial}

There was still the problem of how to actually prosecute hundreds of individuals for large numbers of decades-old crimes within the confines of due process. Different countries have assayed a number of paths to do so. Argentina has been the most innovative in dealing with the challenges of trying large numbers of perpetrators while respecting both defendants' rights to a fair trial and the rights of victims. The courts invalidated the "due obedience" and amnesty laws starting in 2001, and the legislature followed suit in 2003. The Supreme Court affirmed in 2005.

In the post-amnesty period, judges and prosecutors sought to extend prosecutions throughout the country. Owing in part to backlash against the "due obedience" law, which had been limited to commanders, the law did not require prosecutors to focus on individuals at the top of the command chain; anyone who participated, directly or indirectly, in detaining, torturing, or killing was subject to prosecution. Moreover, during the period when the amnesty laws were in effect, judges and civil society groups had organized "truth trials" aimed at discovering what had happened to each victim, even if the perpetrators were immune. ${ }^{37}$ These trials set a precedent for including each and every person involved in the crime within the ambit of the hearing. Of course, there were some intrinsic limits: Many perpetrators were dead or dying, others were in hiding, and still others were unknown because everyone had been killed and there were no witnesses.

At first, chaos erupted. The federal courts that had centralized the earlier pre-amnesty investigations sent the files to provincial courts throughout the country. Local judges and prosecutors began putting together case dossiers on the former military commanders, detention camp personnel, and other repressors within their territory, but with no overall strategy. Varying numbers of investigations that had been underway in different areas of the country in

36. Neha Jain, The Control Theory of Perpetration in International Criminal Law, 12 CH. J. INT'L L. 159, 181-82 (2011); Florian Jessberger \& Julia Geneuss, On the Application of a Theory of Indirect Perpetration in Al Bashir: German Doctrine at The Hague?, 6 J. INT'L CRIM. Just. 853, 857 (2008). The International Criminal Tribunals for the Former Yugoslavia and Rwanda, in contrast, relied heavily on a theory of Joint Criminal Enterprise, which considers each member of an organized group individually responsible for crimes committed by the group within a common plan or purpose. See Allison Marston Danner \& Jenny S. Martinez, Guilty Associations: Joint Criminal Enterprise, Command Responsibility, and the Development of International Criminal Law, 93 CAL. L. Rev. 75 (2005).

37. See Roht-ArriaZa, supra note 17 , at $97-117$. 
the 1980s could now be reopened, and courts reopened these investigations at different times. There was little uniformity in how broadly judges cast their nets, or in how they prioritized cases. ${ }^{38}$ Many judges and local prosecutors investigated the complaints that came before them and treated the cases like any other common crime. They did not inquire whether other cases, involving the same defendants or nucleus of facts, were pending before them. It soon became clear that, without changes, cases would drag on for decades, victims would end up testifying over and over again about the same facts, the trials would appear arbitrary, and the proceedings would not reflect the systematic nature of the crimes.

The first step toward a coherent strategy came from prosecutors, who formed a Prosecutors' Coordination Unit in March 2007 and began to develop common goals and methods. The goal was to consolidate every case regarding a single massacre or place of detention; ideally a single trial would involve all the victims and all the accused. In 2008, the Chief Prosecutor circulated a strategy document ${ }^{39}$ that contained two directives: First, prosecutors should immediately set for trial those cases with sufficient evidence, without waiting to combine cases or to conduct further investigation. This directive was aimed at quieting criticism that few of the cases that had already been fully investigated back in the 1980s had actually come to trial. In the rest of the cases, prosecutors were to consolidate so that, at the point of making charging decisions, they would charge together all the participants who had played a role in related incidents.

Getting prosecutors to work according to a common set of standards was a good first step, but in Argentine criminal practice, the judge is in charge and is the one who decides the scope of cases and the frequency of hearings. Some judges scheduled trials for only a few hours a week, so that proceedings dragged on-for almost two years in some cases. Prosecutors could try to convince the judges to work according to common standards, but they could not force the judges to do so, and not all judges were enthusiastic about these cases. However, in December 2008, the Supreme Court weighed in with an acordada aimed at streamlining and speeding up the trials. An acordada is simply an agreement on practical or administrative matters; it is often used to address topics like court holidays. This particular acordada recognized that there had been too many delays, in part due to the concentration of cases in federal courts in the capital, and in part due to a shortage of judges. They declined to order the consolidation of cases,

38. Pablo F. Parenti \& Iván Polaco, Perspectiva Nacional Argentina, in Selección y Priorización como Estrategia de Persecución en los Casos de Crímenes Internacionales: Un Estudio Comparado 131 (Kai Ambos ed., 2011).

39. Id. at 172; Resolución PGN 13/08, Resolución del Procurador General de la Nación Dando Instrucciones a los Fiscales en los Casos de Crímenes Contra la Humanidad [Resolution of the Prosecutor General of the Nation Giving Instructions to Prosecutors in Cases of Crimes Against Humanity] 3 Mar. 2008. 
saying that in some cases consolidation could make the delays worse, and instead asked each judge to work with the prosecutor to do whatever was necessary to speed up the cases. They created a Superintendency within the judiciary to advise and serve as a clearinghouse. ${ }^{40} \mathrm{~A}$ further acordada from the Federal Chamber of Criminal Cassation made it more difficult to bring interlocutory challenges, which had created endless delays, and mandated a pretrial scheduling hearing. ${ }^{41}$ Additional pressure came from the Commission for Coordination and Facilitation of Cases involving Crimes Against Humanity, composed of the Prosecutors' Office, the Ministry of Justice, the Congress, and the courts. ${ }^{42}$

As the number of cases reaching conviction slowly grew, from thirtynine in 2007 to 378 in 2012 (with forty-four acquittals), ${ }^{43}$ concerns for both victims' and defendants' rights arose. From the victims' perspective, consolidation of all the trials involving a given detention center or event was crucial in avoiding the need to repeatedly testify about each individual victim or perpetrator found at the site. Some survivors of detention camps were potentially witnesses to the fate of hundreds of victims; testifying could have become a full-time occupation. In addition to consolidation of cases, the 2012 acordada encouraged the videotaping of all witness testimony, under oath and with defense counsel present. Videos of the prior testimony of witnesses or experts could then be introduced in subsequent cases, either related or not. If one of the parties objected and wanted the witness to appear in person, that party was required to detail what they would ask that was different. In doing so, they were directed to take into account the effect on the witnesses' emotional and mental health and the possibility of intimidation or reprisals. ${ }^{44}$

40. Corte Suprema de Justicia de la Nación [National Supreme Court of Justice] 29 Dec. 2008, Acordada No. 42/08, Expediente No. 6020/08 (Arg.).

41. Cámara Federal de Casación Penal [Federal Chamber of Criminal Cassation] 19 Mar. 2012, Reglas Prácticas para Asegurar el Debido Proceso, Acordada No. 1/12 (Arg.), available at http://www.iaepenal.com/index.php?option=com_content\&view=article\&id=506:cfcp $\&$ catid $=64: \mathrm{cncp} \&$ Itemid $=124$. This agreement includes not only crimes against humanity cases, but also those involving sexual violence, organized crime, or corruption.

42. Informe de Gestión de la Unidad Fiscal de Coordinación y Seguimiento de las Causas por Violaciones a los Derechos Humanos Cometidas Durante el Terrorismo de Estado (Operations Report of the Prosecutors' Unit for Coordination and Monitoring of the Cases of Human Rights Violations Committed During the Period of State Terrorism), Procuración General de la Nación 12-13 (2011), available at http://www.mpf.gov.ar/docs/ RepositorioW/DocumentosWeb/LinksNoticias/Informe_Anual_2011_DDHH.pdf.

43. Informe de Gestión de la Unidad Fiscal de Coordinación y Seguimiento de las Causas por Violaciones a los Derechos Humanos Cometidas Durante el Terrorismo de Estado (Operations Report of the Prosecutors' Unit for Coordination and Monitoring of the Cases of Human Rights Violations Committed During the Period of State Terrorism), Procuración General de la Nación 7 (2012), available at http://www.mpf.gov.ar/docs/Links/ DDHH/Informe_Anual_2012_DDHH.pdf. Only fifty-five of those have exhausted all their appeals. Id. at 11 .

44. Id. at 2, 25 . 
From the defense perspective, the sheer number of defendants involved in a single trial posed potential problems as consolidation proceeded. For example, a case involving the detention center at the naval base in Bahia Blanca involved seventeen defendants and ninety-two victims; in a trial in Mar del Plata there were twenty-eight defendants accused in 155 related cases. The biggest "mega-trial" to date involves the Naval Mechanics' School (ESMA), where over 5,000 people were secretly detained over many years, and where a relatively large number of victims survived to testify. The first ESMA trial involved only one defendant. The second tried eighteen defendants in eighty-six cases that had been investigated in the 1980s. The third unified trial of the remaining cases has sixty-eight defendants and 789 victims; over 900 people are expected to testify. ${ }^{45}$ The second trial took almost two years. To speed up the current proceedings, the trials now run three days a week, all day. The defendants are not required to attend and are either under house arrest or in jail. Their lawyers, each representing from one to ten defendants, fill up one side of the courtroom, while the prosecutors and victims' representatives occupy the other.

Victims generally do not have individual lawyers, but can choose to be represented by one or more NGOs, who are the only ones able to finance representation. The victims' lawyers serve as an interface between victims and the prosecution, and are able to independently question witnesses and defendants, as well as to offer their own evidence. The defense lawyers often co-represent defendants, and the public defenders (over half the defendants are considered indigent) coordinate their appearances. The consolidation of all the cases involving a single detention center or incident tends to minimize finger-pointing and conflicts of interest among defendants, because the focus is not on who tortured or killed which specific individuals, but rather on whether each defendant was a co-perpetrator of the crimes committed at a particular place during the relevant period. Consolidation also minimizes due process concerns about joint representation, although defendants must obtain separate counsel if conflicts arise. The multiplicity of parties does not slow the proceedings down excessively; rather, the significant delays arise mostly from efforts to recuse judges or prosecutors, or from a bottleneck at the Criminal Cassation Court, which must consider defendants' appeals.

Colombia, like Argentina, has grappled with the question of how broadly to extend the net of criminal investigations. ${ }^{46}$ In discussing the constitutional reforms needed in the context of a possible peace agreement with the FARC,

45. See Ed Stocker, Victims of "Death Flights": Drugged, Dumped by Aircraft-but not Forgotten, THE INDEPENDENT, 21 Jan, 2015, available at http://www.independent.co.uk/ news/world/americas/victims-of-death-flights-drugged-dumped-by-aircraft--but-notforgotten-8360461.html.

46. In a December 2012 revision of a law regulating the demobilization of members of paramilitary groups, the legislature mandated a policy of "prioritization" of cases, under 
the Constitutional Court addressed the creation of consolidated "mega trials" like those in Argentina. It approved a system that "departs from case by case consideration in order to group cases into macro-processes that target those most responsible." ${ }^{47}$ Chile, while generally trying smaller cases, has also established a coordination office and a database of related cases with the goal of ensuring that every recognized victim's case is part of an investigation. ${ }^{48}$

As time went on and the major architects of the repression were tried and convicted, attention turned to a wider group of crimes and accused parties. Prosecutors looked beyond military coups, and beyond organized military structures, to the civilian masterminds and accomplices. Judges, lawyers, doctors, priests, and business executives have been charged, and some have been convicted. On 1 November 2007, Christian von Wernich, a Catholic priest who counseled the Argentinian military, was convicted of participation in torture and sentenced to life imprisonment. ${ }^{49}$ In December 2012, former judge and prominent attorney Jaime Lamont Smart was sentenced to life in prison for his participation in repressive activities in Buenos Aires province.$^{50}$ Three managers of the Ford Motor Company plant were indicted for participation in the illegal detention and torture of trade union activists at the Ford plant, where an army detachment set up shop during the 1970s. ${ }^{51}$ A case was also opened against one of the managers of Mercedes Benz for

criteria to be decided by the Chief Prosecutor. The law, in Article 13, specifies that these criteria are to aim at clarifying the patterns of macro-criminality among the paramilitary groups, and to reveal the contexts, causes, and motives of their actions. It also tries to streamline the process, allowing joint or collective unsworn statements, as well as indictment and disposition in a single hearing for all those fighters involved in the same group. Along the same lines, if the pattern of macro-criminality has already been well documented in another case, individuals can ask to adopt the findings of the earlier case and shorten the proceedings. Ley No. 1592, 3 Dec. 2012, Diario Oficial (Colom.). The 2005 Justice and Peace Law and the 2013 Framework for Peace are discussed further below.

47. Boletín de Prensa de la Corte Constitucional, Colombian News, 30 Aug. 2013, available at http://periodicodebate.com/index.php/nacion/politica/item/2240-textos-sobre-fallosobre-marco-jur\%C3\%ADdico-para-la-paz.

48. Centro de Derechos Humanos, Universidad Diego Portales, Informe Anual Sobre Derechos Humanos en Chile 2014, 38 (Tomás Vial Solar ed., 2014).

49. See Duilio Ferro, Guillermo González \& Marta Vedio, La Iglesia Analiza Posibles Sanciones a Von Wernich, El JUICIO A Christian (6 Nov. 2007), available at https://juicioavonwernich.wordpress.com/2007/11/06/la-iglesia-analiza-posibles-sanciones-a-von-wernich/.

50. Juan Ignacio Irigaray, El ex Juez Jaime Lamont Smart, Primer Civil Condenado por "Genocidio," El Mundo, 19 Dec. 2012, available at http://www.elmundo.es/america/2012/12/20/ argentina/1355969897.html. He is the second judge convicted for these crimes, and several more judges are under indictment.

51. See Victoria Basualdo, Tomás Ojea Quintana \& Carolina Varsky, Los Casos de Ford y Mercedes Benz, in Cuentas Pendientes: Los Cómplices Económicos de la Dictadura 185 (Horacio Verbitsky \& Juan Pablo Bohoslavsky eds., 2013). See also Ex-Ford Execs Charged in Argentine Tortures, USA TODAY, 21 May 2013, available at http://www.usatoday.com/ story/news/world/2013/05/21/ford-execs-argentine-torture/2347861/. 
complicity in the disappearance of workers at that plant. ${ }^{52}$ Other cases followed against large landowners, civilian officials, and private death squads.

Prosecutors also belatedly turned their attention to rape and other crimes of sexual violence. In Argentina, while these cases were technically omitted from the due obedience laws, they were never prosecuted in the first wave of cases in the 1980s. Many judges refused to charge rape and sexual violence as separate crimes, considering them a subspecies of torture. Others saw rapes as aberrations or personal frolics, rather than as an integral part of the dehumanization and degradation of prisoners within a systematic plan. ${ }^{53}$ Moreover, survivors in the first cases chose to focus their testimony on identifying those who had died and those responsible, not on their personal survival stories. ${ }^{54}$ However, a new crop of judges, and increased international attention to systematic rape as an international crime, led to efforts by civil society to encourage prosecutors to recognize the systematic and integral nature of sexual violence as part of the practices of clandestine detention.

Colombia, like Argentina, has expanded prosecutions of paramilitary leaders to the civilian parapolíticos who did the paramilitary's bidding in the legislature, governorships, and mayoralties. However, the charges against senators and other political leaders so far have been limited to unlawful association and have not addressed the underlying war crimes or crimes against humanity. ${ }^{55}$ Colombia has also pioneered prosecutions for new aspects of international crimes. For example, in a recent prosecution of a paramilitary leader, a trial court found the accused guilty of forced displacement, both as a war crime and as a crime against humanity. The court recognized that forced displacement violates a wide range of rights, and that it is used not only to confer a military advantage, but also to cause the degradation of the armed conflict, to dispossess civilians of their land, and to enrich the armed

52. When both cases stalled in Argentina, the workers' representatives brought civil suits in US courts under the Alien Tort Statute. The Mercedes-Benz case was dismissed by the US Supreme Court in Daimler AG v. Bauman, 134 S.Ct. 746 (2014). The Ford case was not pursued after the Supreme Court's 2013 Kiobel v. Royal Dutch Petroleum Co. decision made suits based on conduct outside the US much more difficult. See 133 S.Ct. 1659 (2013).

53. See Lorena Balardini, Ana Oberlin \& Laura Sobredo, Violencia de Género y Abusos Sexuales en los Centros Clandestinos de Detención, in Hacer Justicia: Nuevos Debates Sobre el Juzgamiento de Crímenes de Lesa Humanidad en la Argentina 167-226 (2011).

54. The tendency of women to focus on what happened to others, not to themselves, has been noted in other truth-seeking efforts. See, e.g., Fiona C. Ross, Bearing Witness: Women and the Truth and Reconciliation Commission in South Africa 27-50 (2003).

55. See Steven Cohen, Senate Sets Date for Uribe Parapolitics Debate, Colombia Rep., 8 Aug, 2014, available at http://colombiareports.co/senate-sets-date-uribe-parapolitics-debate/. See generally Coletta Youngers, Has Incoming Colombian President Santos Inherited a "Captured State"?, Foreign Policy In Focus (7 Aug. 2010), available at http://fpif.org/ colombia_alvaro_uribe_juan_santos/. So far, at least six senators and dozens of other individuals have been indicted for their ties to the paramilitaries. 
actors and their collaborators. ${ }^{56}$ This conviction is one of the first anywhere for forced displacement.

A common complaint about trials in the aftermath of massive violations of human rights and humanitarian law is that they will be unwieldy, impractical, or downright impossible, given the sheer numbers of potential defendants and victims and the limited resources of fragile states emerging from repression or conflict. The ability of Argentine courts to structure trials so as to minimize these problems and carry out viable prosecutions has much to recommend to other "transitional" states. In particular, the consolidation of individual crimes and defendants into "mega-trials," which join all those involved in a given incident or geographical area, helps prosecutors and judges to understand patterns and to discover whether the crimes together meet the "widespread or systematic" element of crimes against humanity and the organization of a criminal plan. ${ }^{57}$ On the other hand, such "mega-trials" could very well raise concerns from defense counsel regarding the broad scope of indictments, often covering all the officials (but not draftees) who worked at a detention center. While the trials have focused so far on actions or culpable omissions within the "widespread or systematic" context-not simply on membership in, or association with, an organization-under different circumstances prosecutors risk overbroad charging.

\section{Focusing Trials: Genocide}

The Argentine and Colombian strategy requires a relatively consolidated judiciary and a modicum of political support from the other branches of government. Where these factors are more fragile and contingent, another strategy may emerge. In Guatemala, for example, rather than attempt to consolidate the thousands of potential cases into mega-trials, the prosecutor decided to focus on a number of high-profile emblematic crimes. ${ }^{58}$ The most

56. Sala de Justicia y Paz del Tribunal Superior del Distrito Judicial de Bogotá [Chamber of Justice and Peace of the Superior Tribunal of the Judicial District of Bogotá], 1 Dec. 2011, Sentencia e incidente de reparación integral, José Rubén Peña Tobón et al., đ ๆ 104-07.

57. According to the most widely used definition, a crime against humanity involves murder, torture, deportation, or other crimes committed as part of a widespread or systematic attack on a civilian population. While an organizational plan is not required under customary international law, the crime does require a showing that the attacks were more than fortuitous or random. M. Cherif Bassiouni, Crimes Against Humanity: Historical Evolution and Contemporary Application 19-30 (2011).

58. In addition to the genocide trial described below, these include the massacre of over 200 civilians in the village of Dos Erres, the enforced disappearance of student and labor leaders, and, most recently, the conviction of a former police official for the firebombing of the Spanish Embassy in 1980, resulting in 37 deaths. For details on that case, see Sophie Beaudoin, Guatemala Transitional Justice Update: Reports of Second Rios 
important of these has been the attempt, for the first time in the country's national court system, to try a former head of state for genocide. In this case, it is the elements of the crime itself that allow a single prosecution to demonstrate the broader contours of the events.

The trial of former Guatemalan head of state Efrain Rios Montt marked the new maturity of the courts and prosecutors in that country (and region), while it simultaneously showcased their continuing limitations. Genocide is, of course, by its nature a very difficult crime to prosecute, given the need to prove not just the underlying acts, but also the specific intent to destroy a group. ${ }^{59}$ This becomes much more difficult when the crime happened thirty years earlier, in remote areas of the country, to long-marginalized Mayanorigin peasants; in a country where the military and nonindigenous elites continue to wield power; and where human rights advocates, judges, and prosecutors are routinely threatened and killed-yet that is exactly what the Guatemalan Prosecutor's Office, working with two groups of victims' representatives, attempted from March to May 2013.

Guatemala was a latecomer to the effort to prosecute the crimes of the past. Most of the crimes at issue were committed in the late 1970s and early 1980s, by military and paramilitary forces trying to defeat an insurgency; Rios Montt's rule, within this period, lasted only from March 1982 to August 1983. According to the UN-sponsored Commission on Historical Clarification, 200,000 people were killed overall during the thirty-six year conflict, hundreds of villages were razed to the ground, and 40,000 people disappeared. The Commission's 1996 report characterized the army's conduct in several specific regions as "acts of genocide," but few prosecutions followed. Only with the appointment of a new prosecutor in 2010 and Rios Montt's loss of parliamentary immunity in 2012 did trial become possible. ${ }^{60}$

Montt Prosecution and Efforts to Criminally Prosecute Judges, INT'L Justice Monitor (19 Feb. 2015), available at http://www.ijmonitor.org/2015/02/rumors-of-second-rios-monttprosecution-and-efforts-to-criminally-prosecute-judges/.

59. In the Genocide Convention,

[G]enocide means any of the following acts committed with intent to destroy, in whole or in part, a national, ethnical, racial or religious group, as such:

(a) Killing members of the group;

(b) Causing serious bodily or mental harm to members of the group;

(c) Deliberately inflicting on the group conditions of life calculated to bring about its physical destruction in whole or in part;

(d) Imposing measures intended to prevent births within the group;

(e) Forcibly transferring children of the group to another group.

Convention on the Prevention and Punishment of the Crime of Genocide, adopted 9 Dec. 1948, G.A. Res. 260 (III), U.N. GAOR, 3d Sess., art. 2, U.N. Doc. A/RES/3/260 (1948), 78 U.N.T.S. 277 (entered into force 12 Jan. 1951). Thus, a prosecutor must prove both the underlying acts and the specific intent to destroy-at least in part-a listed group because of its characteristics.

60. The prosecutor's original strategy had involved bringing additional genocide charges against Rios Montt's former chief of staff and minister of defense, but they were excused 
The trial of Rios Montt and Rodriguez Sanchez was in some ways more straightforward than other trials involving past international crimes. The charges against the two former military leaders are based on the Guatemalan Penal Code. Since at least 1973, the Penal Code has contained provisions on genocide and "crimes against duties to humanity." 61 Because these provisions have long been part of Guatemalan law-in contrast to other Latin American cases - the trial raised no issues of the lack of international crimes in the Penal Code or the application of retrospective law, and the charges were based directly on the domestic law equivalents of international crimes. Moreover, Guatemala's 1996 amnesty law specifically excludes genocide and other international crimes. ${ }^{62}$ The case was filed in 2001, barely within the twenty-year statute of limitations for genocide.

Defense counsel argued that no genocide had occurred because the intent was to win a counterinsurgency war against a political and military enemy, instead of to destroy an ethnic group, and the army had acted to protect—not harm - the civilian population. There were no written orders to attack civilians, and the military plans that had been presented showed no such orders. Massacres were lamentable "excesses" of war and had been committed by both sides, so it was unfair to try the army but not the guerrillas, they claimed. And in any case, they argued, there was no proof that either of the defendants had personally ordered, supervised, implemented, or even stood in an operational position where he could have ordered the massacres.

The prosecution's strategy relied on a combination of military documents and reports, eyewitnesses, and experts, including dozens of forensics experts who had conducted exhumations of graves in the area. Nearly 100 eyewitnesses and survivors of massacres, mass rape, torture, and destruction testified to repeated patterns of gruesome killings, torture, rape, destruction, and persecution throughout the northern Ixil region, which could not have

from trial on grounds of ill health. Earlier cases involved individual disappearances and emblematic murders, but not genocide. Rios Montt's immunity stemmed from his role as a legislator from 2007 until 2012.

61. Código Penal [Criminal Code] Decreto No. 17-73, arts. 376-78 (1973) (Guat.). Although the latter crime sounds like crimes against humanity, its text actually implements Guatemala's obligations under the 1949 Geneva Conventions.

62. Law of National Reconciliation, supra note 20. The courts have repeatedly denied claims of amnesty under the 1996 law. See Corte de Constitucionalidad [Constitutional Court] 13 Aug. 2013, Apelación de Sentencia de Amparo, Expe. No. 1933-2012 (Constitutional writ filed by Gen. Héctor Mario López Fuentes in the same case) (Guat.). Another amnesty challenge, based on an earlier 1986 law that was overturned by Congress, is still pending. See Emi MacLean \& Sophie Beaudoin, Eighteen Months after Initial Conviction, Historic Guatemalan Genocide Trial Reopens but is Ultimately Suspended, Int'l Justice Monitor, 6 Jan. 2015, available at http://www.ijmonitor.org/2015/01/eighteen-months-after-initialconviction-historic-guatemalan-genocide-trial-reopens-but-is-ultimately-suspended/. 
been the result of lower-level officials' independent decisions. In a day of dramatic testimony, ten women - their faces covered with their shawls-spoke of repeated rape in their communities and sexual slavery at military bases. Experts submitted written reports and gave presentations on the inhumane conditions of life caused by forced displacement and persecution, the nature of gender-related crimes, and much more. Overall, close to fifty experts testified for the prosecution.

A substantial part of the evidence in the case had been previously developed in parallel proceedings in the Spanish National Court. After the Pinochet case, Nobel Prize winner Rigoberta Menchu filed a complaint based on universal jurisdiction in 1999 against high-ranking officials, including Rios Montt. After six years of litigation over jurisdiction that resulted in a 2005 victory for complainants, lawyers working closely with their counterparts in Guatemala began developing the genocide theory in the Spanish court. Spanish judge Santiago Pedraz eventually sought extradition for the defendants. When Guatemala's Constitutional Court (the country's highest court) refused to allow extradition, the complainants brought eyewitnesses and experts to Spain to testify. Their evidence and statements were made available to the Guatemalan prosecutor's office in preparation for trial. Many of the experts who testified at the trial had also done so in pretrial investigations in Madrid,${ }^{63}$ pioneering the use of multi-jurisdiction lawyering in national courts.

All the prosecution's evidence was extensively reproduced in the 10 May 2013 verdict. $^{64}$ The judges explained, in almost 800 pages, why each piece of evidence showed the necessary elements of genocide and crimes against obligations to humanity. The panel of judges found Rios Montt guilty on both counts for organizing and ordering the plans, and for failing to stop the acts, despite indisputably knowing of them. His intelligence chief, Rodriguez Sanchez, was acquitted on both counts on grounds that he had no operational responsibilities and so could not have ordered or stopped the crimes.

The prosecution's theory of the case, which the trial court accepted, was that there had been intent to destroy the Ixil-Maya people in part-that segment of the Ixil-Maya people who refused to submit to army domination. ${ }^{65}$ The Ixil-Maya people are easily characterized as an ethnic group; they speak their own language (many witnesses testified in Ixil) and have

63. The story of the Spanish proceedings is told in Naomi Roht-Arriaza, Making the State Do Justice: Transnational Prosecutions and International Support for Criminal Investigations in Post-Armed Conflict Guatemala, 9 CHI. J. INT'L L. 79 (2008).

64. For an English summary and translation of the judgment, see EMI MACLEAN, JudGING A Dictator: The Trial of Guatemala's Ríos Montt 12-16 (2013).

65. Although evidence of genocide also exists with respect to a number of other regions in Guatemala, the prosecutor's office chose to focus on the area where the best documentation of military plans and communications existed. Personal communication with Juan Francisco Soto, Director of CALDH (Apr. 2013). 
their own territory and customs. The prosecution put on evidence that they were killed, wounded, and subjected to unbearable conditions of life, and that their children were transferred to another group-all of which are acts constituting genocide. On the key question of specific intent to destroy the group, the prosecution argued-and the court found-that, in its zeal to eradicate leftist guerrillas from the area, and given a backdrop of racism and suspicion against all indigenous people and against the Ixiles in particular, the army defined the entire Ixil people as an "internal enemy" to be subdued or destroyed. While the army's motive may have been counterinsurgency, their intent was genocidal.

The judgment prominently featured crimes of sexual violence and forced displacement. The trial court emphasized the extent and extremity of the cruelty with which crimes of sexual violence (including rape, mutilation, and sexual slavery) were committed to show that these acts could not have been part of a military counterinsurgency strategy. Instead, they constituted evidence of genocidal intent against the Ixil-Maya people. The trial court also relied extensively on expert and eyewitness testimony on the forced displacement of some 29,000 civilians through bombardment and destruction of homes, livestock, and crops, as deliberately inflicting on the group conditions of life that would bring about its partial destruction.

The verdict and sentence was widely disseminated and generated predictably divergent views. However, barely ten days later-on 20 May 2013-the Constitutional Court ordered the sentence annulled and held that the trial must restart from the middle. The order came after the defense's continuous attempts to derail the proceedings through over 100 motions and claims of constitutional violations (known as amparo), many of which were apparently manufactured just to hinder the proceedings. ${ }^{66}$ The majority in the 3-2 Constitutional Court decision held that the trial court did not properly carry out earlier procedural instructions. ${ }^{67}$ The dissenting judges pointed out that there was no harm, much less a constitutional due process problem, because the defense lawyers had already obtained the relief sought. They also noted that, because a verdict had already been issued, the proper recourse for alleged improprieties was through the appeals process, and not through annulment.

66. The "amparo" law, allowing repeated interlocutory appeals based on allegations of a constitutional violation, has been the primary vehicle for delay and political meddling in other high profile cases, and was condemned by the Inter-American Court of Human Rights in an earlier judgment. Myrna Mack Chang v. Guatemala, Judgment, Inter-Am. Ct. H.R. (ser. C) No. 101, ๆ 134.26 (25 Nov. 2003).

67. Although the reasoning is a bit opaque, the essence of the majority's view is that, although the trial court had agreed to suspend the trial pending resolution of jurisdictional issues, the suspension was on its own motion and not explicitly in response to a Constitutional Court ruling, and because it did not follow the proper procedure to hear a recusal motion by one of Rios Montt's lawyers, the verdict and sentence are invalid. See MacLean, Judging a Dictator, supra note 64, for the Court's decision and the dissenting opinions. 
One of the dissenting judges stated openly that the whole issue of recusal had been improperly invented by the defense in order to impede the trial and verdict. The trial court panel then withdrew from the proceedings, as it would be impossible for them to re-rule impartially after having already decided the case. The defendants are thus in limbo awaiting a new trial with a different panel of judges; the proposed retrial date was originally set for early 2015, although additional maneuvers have now resulted in the case's indefinite suspension. ${ }^{68}$

The case demonstrates both the potential and the limitations of national trials for international crimes, as well as of Guatemala's decades of judicial and legal reform. It was not the issues of amnesty, retroactivity, or statutes of limitations that derailed the proceedings. While Judges Barrios, Xitumul, and Bustamante were capable of running a complex trial efficiently and with basic fairness, they were unable, in the end, to manage the concerted defense efforts to create grounds for interlocutory appeals. While the Penal Code and Criminal Procedure Code seemed to make it possible to charge international crimes, the continuing abuse of the (unrelated) writ of amparo that has bedeviled all cases involving powerful defendants-in addition to other procedural labyrinths - has created major obstacles. And the Constitutional Court arguably exceeded its jurisdictional mandate, seemingly with impunity, by improperly deciding questions that the appeals courts should have considered on direct—not collateral—review.

\section{THE THIRD WAVE: LIMITING PROSECUTIONS IN A WORLD WITHOUT AMNESTY FOR INTERNATIONAL CRIMES?}

As this article has discussed, the first wave of litigation revolved around getting cases into court. In the second wave, countries are continuing to test novel methods for actually trying cases. In the countries of Latin America's Southern Cone, relatively limited time frames and numbers of potential defendants made it feasible to investigate and potentially try most of the remaining defendants, although the process has been uneven. In Central American countries, with more protracted conflicts and much higher numbers of potential defendants, prosecutors have focused instead on emblematic leaders and incidents and have used a few cases to illustrate larger patterns. The potential resolution of Colombia's long-running armed conflicts

68. Impediments to a new trial include the fragile health of the defendant, a recusal motion against one of the judges that is making its way through the courts, and another challenge based on an early (1986) amnesty law. Further maneuvers may make trial impossible altogether. Meanwhile, the victims' associations have appealed to the Inter-American system to intervene, alleging a denial of justice. For current information, see MacLean \& Beaudoin, supra note 62 . 
poses an even greater challenge: how to negotiate peace in a world where amnesties for crimes against humanity and war crimes-for all actors, not just state actors - are off the table. Here too, the Colombian example may provide useful lessons.

\section{A. Prosecutorial Policy and a Possible Peace Agreement}

Colombia is grappling with what kind of prosecutorial policy would best serve a process to end a fifty-year-old armed conflict involving multiple actors, with an overlay of links to organized crime and drug trafficking. Rightwing paramilitary groups, the leftist Revolutionary Armed Forces (FARC) and National Liberation Army (ELN), and the government security forces have all been accused of widespread violations of international law. These violations have led to tens of thousands of incidents of killing, torture, forced disappearance, and rape, and have resulted in up to 4 million people being forcibly displaced during the course of the conflict. A process of demobilizing right-wing paramilitaries has been in place since 2005; in 2012, the Santos administration began negotiations with the FARC to demobilize and reintegrate them into Colombian politics.

The negotiations have brought to the forefront the dilemmas of encouraging a sustainable peace deal in a world where amnesty for international crimes is off the table. Colombia incorporates the jurisprudence of the Inter-American Court into its constitutional law; ${ }^{69}$ that jurisprudence, as described above, has categorically rejected amnesties and other impediments to prosecution, even in transitional settings. In addition, some of the crimes at issue would be within the jurisdiction of the ICC; lack of investigation and prosecution of those crimes would leave putative defendants open to an ICC prosecution, which neither the government nor the insurgents want. ${ }^{70}$ That leaves the question of how to feasibly, within a reasonable time, create conditions for investigating and prosecuting these crimes without scuttling peace talks, triggering an unpredictable ICC prosecution, or overwhelming the domestic justice system. In particular, it raises questions on the permissible limits of prosecutions and the question of what, if anything, is to be done with those who are not prosecuted, but who cannot be amnestied. ${ }^{71}$

69. Rodrigo Uprimny, Bloque de Constitucionalidad, Derechos Humanos y Nuevo Procedimiento Penal (2011), available at http://www.wcl.american.edu/humright/hracademy/ documents/Clase1-Lectura3BloquedeConstitucionalidad.pdf.

70. Colombia is a state party to the Rome Statute; the ICC can investigate crimes committed after July 2002 if it finds that Colombia is unable or unwilling to do so. Colombia excluded war crimes committed between 2002 and 2009 from the ICC's jurisdiction, but this does not affect the Court's ability to prosecute crimes against humanity. So if Colombia does not investigate, the Court can open its own investigation.

71. Of course, international law does not prohibit-and even encourages-amnesties for insurgency-related crimes that do not constitute international crimes. See Protocol (II) 
To provide manageable limits to prosecutions given the sheer numbers of fighters and the limited resources of the courts, the concepts of prioritization of, and focus on, "those most responsible" has taken center stage. In July 2012, the Santos government proposed, and Congress passed, an amendment to Article 22 of the Constitution that created a new, transitional provision, known as the Framework Law for Peace, which reads as follows:

A statutory law can authorize that, in the context of a peace agreement, there is differentiated treatment for the various illegal armed groups that have been part of the internal armed conflict and also for state agents in relation with their participation in that conflict...

The criteria of prioritization and selection are inherent to transitional justice. The Chief Prosecutor will determine priority criteria for exercising the prosecutorial power. Without prejudice to the general duty of the State to investigate and sanction grave violations of human rights and international humanitarian law, in a transitional justice framework, the Congress can by law determine selection criteria that allow criminal investigations to focus on those most responsible for all those crimes that can be characterized as crimes against humanity, genocide or systematic war crimes; and can establish the instances, prerequisites and conditions under which the sentence can be executed; and can establish the cases in which extrajudicial sanctions, alternative punishments, or special modalities of execution and serving the sentence are applied; and can authorize the conditional abandonment of criminal prosecution of all those cases that have not been selected for prosecution. The law shall take into account the gravity and representative nature of the cases to determine the selection criteria. ${ }^{72}$

The provision drew a legal challenge from the Colombian Commission of Jurists, a human rights NGO. ${ }^{73}$ While they agreed that some form of prioritization was necessary, they objected to the narrow focus on "those most responsible," combined with the possibility of abandoning prosecution of anyone who was not so selected. They also objected to the exclusion of nonsystematic war crimes. In their view, these provisions were incompatible with the recognized duty of the state to investigate and prosecute all

Additional to the Geneva Conventions of 12 August 1949, and Relating to the Protection of Victims of Non-International Armed Conflicts, 8 June 1977, art. 6(5), 1125 U.N.T.S. 609, 614 (entered into force 7 Dec. 1978), reprinted in 16 I.L.M. 1442 (1977) (providing that, after domestic armed conflict, states should endeavor to provide "the broadest possible amnesty" consistent with international law).

72. Author's unofficial translation. Acto Leg. 1/12, 31 July 2012, "Por medio del cual se establecen instrumentos jurídicos de justicia transicional en el marco del artículo 22 de la Constitución Política y se dictan otras disposiciones" (Colom.).

73. Comisión Colombiana de Juristas, s/ inconstitucionalidad (on file with author). The Framework Law has created strange bedfellows: Some human rights groups oppose the law along with right-wingers like former President Alvaro Uribe and the country's Inspector General, who oppose peace talks, while other human rights groups support the Santos government's efforts. For some of the human rights groups, the mention of "state agents" as being potentially subject to reduced, suspended, or no sentences is particularly worrisome. 
serious violations of human rights and humanitarian law; furthermore, their implementation would lead to a veiled amnesty for almost all perpetrators except the handful who were selected for prosecution. Although the Court would have a subsequent opportunity to review Congress' handiwork, they wanted the justices to provide guidance from the beginning.

On 28 August 2013, the Court upheld the Framework Law. However, it included a number of glosses and additional requirements. Any selection or prioritization had to be transparent, impartial, effective, carried out within a reasonable time and with expert assistance, subject to review, and respectful of the rights of victims to reparations and truth-including the location of the remains of family members. All the crimes that constituted violations of international human rights or humanitarian law, not just a sampling, had to be investigated and then imputed to those most responsible for the crime, who would subsequently be prosecuted. The focus on those most responsible was acceptable to the extent that it limited prosecutions to those who played an essential role in the crimes, allowed the effective dismantling of criminal structures, and facilitated the uncovering of patterns of massive human rights violations. The vote on the issue of selection and prioritization was 7-2. ${ }^{74}$

International human rights law, especially the jurisprudence of the InterAmerican system, does not limit the state's obligation to investigate, prosecute, and remedy violations to any subset of actors or of acts; there is no doctrine limiting the focus to state actors or to "those most responsible." Colombia's choice to direct the Prosecutor to focus on "those most responsible" is in part borrowed from the international and internationalized courts. The ICC's Office of the Prosecutor has also declared that it will focus on those who bear the greatest responsibility, such as the leaders of the state or organization that committed the crimes. ${ }^{75}$ Focusing on the top leaders makes sense from both a resource-allocation and a moral perspective. However, it is not at all clear that simply adopting the criteria of international or hybrid courts with limited and specific mandates makes sense for national prosecutions. ${ }^{76}$

74. Corte Constitucional [Constitutional Court] 23 Aug. 2013, Marco Juridico para la Paz (Legal Framework for Peace), Sentencia No. C579-13 (Colom.).

75. Paper on Some Policy Issues before the Office of the Prosecutor, ICC-OTP, at 7 (Sept. 2003), available at http://www.icc-cpi.int/nr/rdonlyres/1fa7c4c6-de5f-42b7-8b2560aa962ed8b6/143594/030905_policy_paper.pdf. The statutes of the Special Court for Sierra Leone and the Extraordinary Chambers of the Courts of Cambodia direct these "hybrid" courts to focus on "those most responsible." Statute of the Special Court for Sierra Leone, adopted 14 Aug. 2000, S.C. Res. 1315, U.N. SCOR, 4186th mtg., art. 15, U.N. Doc. S/RES/1315 (2000); Law on the Establishment of Extraordinary Chambers in the Courts of Cambodia for the Prosecution of Crimes Committed During the Period of Democratic Kampuchea, NS/RKM/1004/006, art. 8 (as promulgated 27 Oct. 2004).

76. In the case of the ICC, the Prosecutor's decision to focus on top leaders assumes that national courts will take responsibility for prosecuting lower-level offenders. See ICCOTP, Paper on Some Policy Issues, supra note 75, at 7. 
Too narrow of a definition of who falls within that category raises a number of concerns. If "most responsible" is defined simply in terms of de jure position at the top of a military or civilian hierarchy, those individuals may not actually be the ones who made the key operational decisions. As Xabier Agirre points out, large-scale criminal structures can take a number of forms, including concentrating power in a leader or dispersing it through networks, only some of whose members may hold high rank. ${ }^{77}$ Just as importantly, merely focusing on those at the top of a bureaucratic structure may draw the net of responsibility too narrowly and may exclude informal leaders, political backers, or those who committed notorious or particularly atrocious crimes. Indeed, even Argentina's 1980s trial strategy, while focusing on members of the governing Juntas, also included those who had committed "atrocious and aberrant" acts. ${ }^{78}$ In Rwanda, while "category 1" criminals subject to formal national trials were defined as planners, organizers, instigators, supervisors, and leaders, or those in positions of authority, the category also included "notorious murderers who by virtue of the zeal or excessive malice with which they committed atrocities, distinguished themselves in their areas of residence or where they passed." ${ }^{\prime 79}$

Especially in a large, diverse country, the form and nature of the conflict may have varied greatly from one region to another, and from the perspective of local people, a regional or even local commander may be far more responsible for the crimes they experienced than someone farther away and more highly ranked. An overly narrow definition would also exclude those who, from behind the scenes, as members of powerful economic or political groups, pulled the strings of military or paramilitary structures. Thus, a more complete definition of those "most responsible" would combine leadership position with the gravity or scale of the crime; be attuned to regional and local, as well as national, dynamics; and address the links between legal and illegal actors. ${ }^{80}$

The Colombian prosecutors' office has begun dealing with prioritization issues along the lines suggested above, in the context of prosecutions of

77. Xabier Agirre Aranburu, Prosecuting the Most Responsible for International Crimes: Dilemmas of Definition and Prosecutorial Discretion, in Protección Internacional de Derechos Humanos y Estado de Derecho 381-404 (J. Gonzalez ed., 2009). This observation may be particularly relevant in conflicts like that in Colombia, where narcotics trafficking, extortion, kidnapping, and other criminal activities are deeply intertwined with political motivations.

78. Ley No. 23.049, 9 Feb. 1984, Código de Justicia Militar, Modificaciones, art. 11, Buletín Oficial 15 Feb. 1984 (Arg.). This law reformed the Law of Military Justice and stated that the principle of due obedience did not apply to "atrocious and aberrant" crimes.

79. Organic Law No. 08/96, 30 Aug. 1996, Organization of Prosecutions for Offences Constituting the Crime of Genocide or Crimes Against Humanity Committed since 1 October 1990, art. 2(c) (Rwanda).

80. See generally Laura Arriaza \& Naomi Roht-Arriaza, Social Reconstruction as a Local Process, 2 INT'L J. TRansitional Just. 152 (2008). 
paramilitary groups. Reminiscent of Argentina, it created an advisory Unit on Prioritization of Situations and Cases, ${ }^{81}$ as well as a Unit on Analysis and Contexts, in charge of finding patterns and connections among disparate acts, and of reconstructing informal chains of command. With respect to defining "those most responsible," the current definition creates two different categories: "(1) the person who, within the command and control structure of the criminal organization knew or could reasonably foresee the perpetration of crimes as part of the execution of operations plans, and (2) exceptionally, those persons who have committed particularly notorious crimes, independently of the position that they occupied within the criminal organization." ${ }^{2}$ This is a potentially broad view of "maximum" responsibility, encompassing mid-ranking figures, as well as top commanders.

The prioritization policy combines three elements:

1. Subjective: Takes into account the particular qualities of the victim (member of an ethnic (N.B. indigenous or Afro-Colombian) group, minor, woman, human rights defender, displaced person, judicial officer, journalist, labor union member), as well as the perpetrator (most responsible, instigator, collaborator, financier, material author of the crime).

2. Objective: Analyzes the class of crime, its gravity and representativeness in terms of affecting the fundamental rights of the victims in particular and the community in general, and the manner of commission of the crime.

3. Complementary: Criteria like the region or locality where the crimes were committed; abundance of evidence and viability of the case; the scrutiny of the case by an international human rights body and its explanatory richness, among others. ${ }^{83}$

The prioritization scheme envisions a focus on crimes committed by criminal organizations, but allows for placing other crimes of high social impact on the list, taking into consideration their gravity in terms of affecting the victims' fundamental rights, the legal rights involved, or their capacity to expose the existence of discriminatory cultural patterns. How all these elements are to be balanced against each other remains to be seen. Addi-

81. Created by: Resolución No. 1811, 4 Oct. 2012, "Por medio de la cual se crea y reglamenta el Comité de Priorización de Situaciones y Casos en la Fiscalia General de la Nación", available at http://www.fiscalia.gov.co/colombia/wp-content/uploads/2013/02/0-1811-12. pdf.

82. Fiscalía General de la Nación, Conceptos, Priorización (15 Mar. 2013), available at http:// www.fiscalia.gov.co/colombia/priorizacion/conceptos/.

83. Fiscalía General de la Nación, Criterios de Priorización, Priorización (15 Mar. 2013), available at http://www.fiscalia.gov.co/colombia/priorizacion/criterios-de-priorizacion/. 
tionally, because these concepts and criteria were developed in the context of the Justice and Peace Law and prosecution of paramilitary groups, they may need to be modified to deal with prosecutions against insurgents and/ or government officials.

While the selection issue is problematic, the treatment of those not selected or prioritized has been even more contentious. If those who are "most responsible" are to be prosecuted and punished, what happens to those who are deemed not most responsible, and yet have been allegedly involved in serious violations of human rights and humanitarian law, when amnesty is not available? The Colombian framework law provides, and the Constitutional Court upheld by a 5-4 vote, alternative sentencing provisions for those who are not considered "most responsible" for a particular crime. To pass constitutional muster, the Court held that any alternative sentence would have to satisfy the rights of victims to truth, justice, reparation, and guarantees of non-repetition, and could be subject to conditions. Members of groups taking advantage of the law had to agree to turn over their arms, desist from engaging in further fighting, accept their responsibility, liberate kidnapping victims, and release child soldiers.

Colombia has already experimented with using alternative and reduced sentences as an incentive for fighters to come forward, tell their story, and agree to lay down their arms. The country's 2005 Justice and Peace Law, for example, was passed in the context of the demobilization of right-wing paramilitary groups. The Law promised conditional suspension after a hearing of the normal sentences for murder and other serious crimes, to be replaced by an alternative five- to eight-year sentence. In exchange, the applicant was required to commit to demobilization, give an unsworn public statement detailing his crimes, and turn over any lands or other property stolen as a result of paramilitary activities. Unfortunately, after years in operation and 4,000 demobilization applications, the law had only yielded fourteen convictions as of 2012, only one of which has been finalized on appeal. ${ }^{84}$ As noted above, the December 2012 revision of the Justice and Peace Law attempts to deal with the low conviction rate, as well as with tweaking the alternative punishment provisions to create greater accountability for those who avail themselves of the provisions and then fail to comply with the conditions imposed. But it is not at all clear that these measures will be enough to remedy the law's defects.

The notion of alternative punishments could encompass reduction in sentences or grants of parole/probation, variance in the conditions under which the sentence is served, or the possibility of noncustodial alternatives.

84. See Fiscalía General de la Nación, Estadísticas Unidad Nacional de Fiscalías para la Justicia y Paz, JUSTICIA TRANSICIONAL, available at http://www.fiscalia.gov.co/jyp/unidad-dejusticia-y-paz/; Ley 975 de 2005, 25 July 2005, Ley de Justicia y Paz, Diaro Oficial No. 45.980 (Colom.). 
The discussion on alternative punishments in the peace process context envisions a conditional exchange of lessened punishment for, at a minimum, a full and complete declaration of facts (including where bodies and stolen riches are to be found), an apology or recognition of harm, and a commitment to permanently demobilize. However, a conditional amnesty patterned on the South African truth-for-amnesty mode ${ }^{85}$ is unlikely, given the demonstrated inability of the Colombian court system to actually investigate whether applicants have made full and truthful declarations - as shown by the Justice and Peace experience. Some kind of ability to retract any benefit conferred if the applicant turns out to have been untruthful may be the best option for enforcing conditionality.

The international law on post-conviction reductions of sentence or conditions of detention is much less developed than that regarding preconviction obligations. The basic anti-impunity norm speaks to obligations to investigate, prosecute, and punish, but says nothing about the duration or conditions of punishment. Treaties on torture require punishment of crimes to include "appropriate penalties which take into account their grave nature." ${ }^{186}$ The InterAmerican Court has held that punishment should be "proportional" to the seriousness of the crime. ${ }^{87}$ In the La Rochela Massacre case, the Court held:

With regard to the principle of proportionality of the punishment, the Court deems it appropriate to emphasize that the punishment which the State assigns to the perpetrator of illicit conduct should be proportional to the rights recognized by law and the culpability with which the perpetrator acted, which in turn should be established as a function of the nature and gravity of the events. The punishment should be the result of a judgment issued by a judicial authority. Moreover, in identifying the appropriate punishment, the reasons for the punishment should be determined. With regard to the principle of lenity based upon the existence of an earlier more lenient law, this principle should be harmonized with the principle of proportionality of punishment, such that criminal justice does not become illusory. Every element which determines the severity of the punishment should correspond to a clearly identifiable objective and be compatible with the Convention. ${ }^{88}$

85. See generally Alex Boraine, A Country Unmasked: Inside South Africa's Truth and Reconciliation Commission (2000).

86. Convention Against Torture and Other Cruel, Inhuman or Degrading Treatment or Punishment, adopted 10 Dec. 1984, G.A. Res. 39/46, U.N. GAOR, 39th Sess., art. 4(2), U.N. Doc. A/39/51 (1985), 1465 U.N.T.S. 85 (entered into force 26 June 1987). The International Convention for the Protection of All Persons from Enforced Disappearance refers to penalties "which take into account its extreme seriousness." International Convention for the Protection of All Persons from Enforced Disappearance, supra note 8, art. 7(1). No other treaties on international crimes specify punishment obligations. The Convention on the Prevention and Punishment of the Crime of Genocide, supra note 59 , art. 5, merely requires "effective penalties."

87. Rochela Massacre v. Colombia, Judgment, Inter-Am. Ct. H.R. (ser. C) No. 163 (11 May 2007).

88. Id. ๆ 196. 
These considerations, at least, would seem to exclude the outright suspension of sentences. Nonetheless, some members of the Inter-American Court have recently signaled a willingness to view proportionality alongside other values. In his concurring opinion in the El Mozote case (involving a massacre during El Salvador's civil war), Inter-American Court Judge Diego Garcia-Sayán pointed out that the Court's previous amnesty decisions were not issued in the context of peace negotiations. Calling for a nuanced approach in such cases, he seemed to agree with the Colombian government's approach:

[I]t is necessary to devise ways to process those accused of committing serious crimes such as the ones mentioned, in the understanding that a negotiated peace process attempts to ensure that the combatants choose peace and submit to justice. Thus, for example, in the difficult exercise of weighing and the complex search for this equilibrium, routes towards alternative or suspended sentences could be designed and implemented; but, without losing sight of the fact that this may vary substantially according to both the degree of responsibility for serious crimes and the extent to which responsibility is acknowledged and information is provided about what happened. This may give rise to important differences between the "perpetrators" and those who performed functions of high command and gave the orders.

It is relevant to consider the shared responsibilities of those involved in an armed conflict with regard to serious crimes. The acknowledgment of responsibility by the most senior leaders can help promote a process of clarifying both the facts and the structures that made such violations possible. Reduction of sentences, alternative punishments, direct reparation from the perpetrator to the victim, and public acknowledgment of responsibility are other ways that can be considered. ${ }^{89}$

While some judges on the Inter-American Court may be open to considering alternatives, the International Criminal Court recently signaled that it would take a hard line. The ICC's Prosecutor, in two letters addressed to the country's constitutional court, argued that the Rome Statute requires some incarceration as punishment for international crimes. On 26 July 2013, Prosecutor Bensouda wrote that "The decision to suspend a prison sentence would suggest that the proposed judicial process has the purpose of removing the accused from his criminal responsibility," thus potentially triggering the ICC's jurisdiction. ${ }^{90}$ This dual jurisdiction thus allows flexibility as to length of sentence, but does not allow complete suspension.

89. El Mozote Case, supra note 14, concurring opinion ब ब 30-31.

90. Cited in Colombian Constitutional Court, Case No. C-579-13, supra note 74, ๆ 3.16.1. The Rome Statute is silent on what punishments are acceptable in domestic courts, although it specifies imprisonment, fines and forfeiture as punishments the Court itself may impose. It also, in Rome Statute, supra note 18, art. 80, clarifies that "Nothing in this Part [regarding sentencing] affects the application by States of penalties prescribed by their national law, nor the law of States which do not provide for penalties prescribed in this Part." 
Despite the difficulty of suspending sentences, the option remains to create relatively lenient conditions of confinement. In another case before the Inter-American Court of Human Rights, the Court elaborated that not only the length of the sentence, but also the conditions of confinement were relevant to the proportionality inquiry. In the case of Manuel Cepeda Vargas v. Colombia, ${ }^{91}$ the perpetrators of the extra-judicial execution of a political activist had their sentences reduced, and were ultimately able to serve part of their sentences in a low-security military prison used for purely military offenses rather than serious common crimes. While there, they left the prison grounds to commit further crimes. The Court stated that

Under the rule of proportionality. . . . States must ensure that the sentences imposed and their execution do not constitute factors that contribute to impunity, taking into account aspects such as the characteristics of the crime, and the participation and guilt of the accused. ${ }^{92}$

The Court further explained that the reduced sentences, combined with the ability to leave the prison at will, indicated that the state had "made an insufficient effort to prosecute and punish adequately serious human rights violations." ${ }^{\prime 93}$

\section{B. Regional Trends on Sentencing and Confinement Conditions}

National courts in the region have a mixed record on sentencing severity and conditions of confinement. In part, these differences are due to the length of time it has taken to arrive at conviction and sentencing in these cases, and responds to humanitarian concerns for the now aged and infirm prisoners. Nonetheless, despite the international jurisprudence cited above, the demise of amnesty has coincided with a rise in leniency in post-conviction arrangements. Argentina originally placed most of those awaiting trial, or those whose cases were on appeal, under house arrest-in part because many were elderly. Over time, the Argentine courts have imposed long sentences and have increasingly required defendants and those convicted to serve their time in regular prisons, instead of at home. ${ }^{94}$ Still, in 2012, almost 40 percent of those detained were under house arrest. ${ }^{95}$ Guatemala has also generally sentenced those convicted to long prison terms.

91. Manuel Cepeda Vargas v. Colombia, Judgment, Inter-Am. Ct. H.R. (ser. C) No. 213 (26 May 2010).

92. Id. ๆ 150.

93. Id. 154.

94. Report of the Prosecutors' Unit for Coordination and Monitoring of the Cases of Human Rights Violations Committed During the Period of State Terrorism, supra note 43, at 12.

95. Id. 
For several years, the Chilean Supreme Court took a more lenient view that, while eschewing outright pardons, did allow for significant reductions in sentencing and probation. From 2007 on, that court has employed a device known as "gradual (or half) prescription" to reduce the sentences of convicted members of the security forces. "Gradual prescription," according to Section 103 of the Criminal Procedure Code, allows a judge to reduce a sentence based on the amount of time between the commission of the crime and the moment when the defendant was charged; if more than half the applicable statute of limitations has run at that point, gradual prescription requires that two mitigating circumstances and no aggravating circumstances be added to the range of permissible sentencing options. Gradual prescription, because it is based on the passage of time and not on the nature of the crime, applies even in cases of international crimes where no statute of limitations can apply. ${ }^{96}$

As a result of this doctrine, former military officers convicted of massacres are often given three- to five-year sentences; under Chilean law, this means that they can serve their sentences entirely on probation with no jail time. The Supreme Court justifies the use of gradual prescription as a reconciliatory mechanism, given the long time that has passed since the crimes, the advanced age of the perpetrators, and their lack of prior or subsequent criminal activity. After national and human rights leaders protested the use of the procedure as a violation of the proportionality that should exist between crime and sentence, the number of sentences applying gradual prescription has declined, but has not ended. ${ }^{97}$ Homicide cases in particular are often subject to the procedure, while in forced disappearance cases, its use is less likely. ${ }^{98}$

96. A logical problem arises when applying gradual prescription to continuing crimes. For example: If there is no body, then there is no starting or ending date for the crime, yet the courts have used the date the person was first abducted to start the clock ticking for sentencing purposes.

97. See Jurisprudential Milestones in Human Rights Cases: Chile 1990-2013, OBservatorio de Derechos Humanos 13 (2014), available at http://www.icso.cl/wp-content/uploads/2011/03/ PRINCIPALES-HITOS-eng22ene2014CC_RH_CC.pdf.The use of gradual prescription may exemplify the distinction between conduct rules and decision rules. Meir Dan-Cohen, Decision Rules and Conduct Rules: On Acoustic Separation in Criminal Law, 97 Harv. L. REv. 625 (1984) examines the distinction between conduct rules of substantive criminal law, which are addressed to the general public and are designed to guide behavior, and decision rules, which are directed to the officials who apply the conduct rules. DanCohen creates an imaginary world in which only officials know the content of decision rules, and only the general public knows the content of conduct rules, a condition he calls "acoustic separation." He argues that, by relying on acoustic separation, society is able to accommodate competing values at stake in the criminal law. Dan-Cohen uses the example of duress to show the consequences of considering a norm as a conduct versus a decision rule, but it could also explain how a conduct rule specifying condemnation of crimes against humanity could coexist with a lenient decision rule specifying punishment. Thanks to Cynthia Lee for pointing this out.

98. See Karinna Fernández Neira, La Jurisprudencia de la Corte Suprema Chilena Frente a las Graves Violaciones Contra los Derechos Humanos, 3 Revista del Magister y Doctorado en Derecho 281 (2009). 
Another option has been to sentence harshly, but to create prison conditions that differ greatly from those of the general prison population. Some of those sentenced-for example, former Peruvian President Fujimori and the Chilean generals-are serving their time in purpose-built prisons with a wide range of amenities, sometimes including tennis courts and open visiting hours. While the Peruvian press has pointed out that Fujimori's prison has every possible amenity, and he has been allowed to attend family weddings and hold political meetings in jail, ${ }^{99}$ the luxurious conditions also serve to defuse political pressures to release him from his twenty-five-year sentence with a humanitarian pardon.

In Chile, while many of those condemned for crimes against humanity are serving probation, those actually incarcerated have been concentrated until recently in two purpose-built military prisons-Cordillera and Punta Peuco - that contain amenities far superior to those of the overcrowded regular prisons. In September 2013, after the press reported on the highly favorable conditions at the prisons, then-President Piñera closed Cordillera, and incoming President Michele Bachelet has promised to consider closing Punta Peuco as well. ${ }^{100}$ While critical of the "country-club" atmosphere in these prisons, victims' organizations have found themselves reluctant to call for harsher conditions of confinement, instead arguing that all prisoners deserve more, not less, humane conditions. A draft legislative bill presently before the Chilean Congress limits post-sentencing privileges for perpetrators of crimes against humanity, but it would probably not be applicable to the existing prison population, even if it passed. ${ }^{101}$

In the Colombian case, one option would be to sentence FARC leaders to a term of imprisonment, but one with lenient conditions of confinement in exchange for confessions or other conditions. According to some analysts, this compromise might be acceptable to them, given the precarious security situation such leaders might otherwise face and their need to reorganize

99. Gisela Ortiz Perea, Lecciones de una Larga Lucha que Llevó a la Sentencia, in LA Trascendencia del Juicio y la Sentencia de Alberto Fujimori: Una Mirada Nacional e Internacional 45, 49 (Rocío Moscoso ed., 2011).

100. Bachelet No Descarta Cerrar Punta Peuco si es Elegida Presidenta, El Mercurio On Line, 3 Oct. 2013, available at http://www.emol.com/noticias/nacional/2013/10/03/622643/ bachelet-baraja-opcion-de-cerrar-penal-punta-peuco-en-caso-de-ser-elegida-presidenta. html. In July 2014, the Chamber of Deputies passed a resolution asking Bachelet not only to close the prison, but also to cancel the pensions and other military privileges of those detained there. Cámara Aprueba Proyecto que Solicita a Bachelet el Cierre de Punta Peuco y el Fin de Privilegios, El CLarin, 23 July 2014, available at http://elclarin.cl/ web/noticias/politica/12477-camara-aprueba-proyecto-que-solicita-a-bachelet-el-cierrede-punta-peuco-y-el-fin-de-privilegios.html.

101. Observatorio de Derechos Humanos, Truth, Justice And Memory For Dictatorship-Era Human Rights Violations, 40 Years After the Military Coup, Centro de Derechos Humanos 22-23 (2013), available at http://www.icso.cl/wp-content/uploads/2011/03/VerdadJusticia-y-Memoria-FINAL-FINAL-ENG-a-5dic2013.pdf. 
as a political entity. ${ }^{102}$ As to crimes committed by government forces, the Framework Law covers them, but leaves Congress to specify how a punishment regime might work.

A final option for Colombia would be to expand the range of sentencing options beyond incarceration. There are only a few relevant examples from other regions of this option in practice, and none of them are from Latin America. The state-created community courts in Rwanda, known as gaçaça, allowed for prison sentences to be commuted to community service when a genocide suspect confessed to participation in genocide but was not a "leader or organizer." Later, community service was extended to those who had served part of their sentence, in an effort to reduce prison crowding and costs, and to improve reintegration of prisoners into their former communities. While the original idea was for prisoners to do their community service at home for three days a week, this arrangement proved largely impracticable. In the end, most community service projects were run as work camps, with large numbers of those serving sentences working on projects like environmental protection or road-building accompanied by education and skills training. ${ }^{103}$

In East Timor, Community Reconciliation Processes allowed minor offenders to avoid prosecution by participating in a public hearing-organized by state officials and usually involving the participation of local traditional and spiritual authorities_-in which they confessed their actions and sought forgiveness from victims. As part of the bargain, they had to carry out specified sanctions, which varied from fixing the victims' house, to helping to repair the school or church on weekends, or to providing the victims with farm animals or clothes. ${ }^{104} \mathrm{~A}$ similar process might be envisioned for rankand-file combatants in Colombia, especially those from indigenous and Afro-Colombian communities with their own cultural traditions.

An additional option is the restriction of political rights for those convicted, at least for a period of time. This option would allow new leadership to emerge and would ensure that those who controlled guerrilla and paramilitary organizations would not play a major political role in post-conflict Colombia.

102. See International Crisis Group, Transitional Justice and Colombia's Peace Talks: Executive Summary and Recommendations, 49 Latin Am. Rep., 29 Aug. 2013, available at http://www.crisisgroup.org/en/regions/latin-america-caribbean/andes/colombia/049transitional-justice-and-colombia-s-peace-talks.aspx; Colombia Peace Process Update, Wash. Office on Latin Am., 15 Nov. 2013, available at http://www.wola.org/commentary/ colombia_peace_process_update_november_15_2013\#transitionaljustice.

103. Paul Christoph Bornkamm, Rwanda's Gacaca Courts: Between Retribution and Reparation 80-83 (2012).

104. Patrick Burgess, A New Approach to Restorative Justice: East Timor's Community Reconciliation Processes, in Transitional Justice in the Twenty-First Century: Beyond Truth versus Justice 193-94 (Naomi Roht-Arriaza \& Javier Mariezcurrena eds., 2006). 


\section{CONCLUSIONS}

These developments provide valuable lessons for other countries trying to manage the aftermath of widespread or systematic violations of human rights. They tell a tale of perseverance, legal ingenuity, and the power of determined activist networks. The first and second waves of cases provide potential solutions to many of the issues of admissibility, amnesty, statutes of limitations, codification of crimes, and nonretroactivity of the criminal law. They also demonstrate procedural and conceptual advances with regard to trying large numbers of defendants. Of course, it is important not to overstate the advances: Many cases are still winding their way through appeals, some high courts have taken a different approach, defendants increasingly claim medical excuses - real or fabricated-from trial or use other delaying tactics, and courts continue to use limiting responsibility doctrines to acquit. And time is working against the victims.

While all legal systems have their peculiarities, the issues raised in these trials are common to many civil law, as well as common law, jurisdictions. Beyond their utility in other national trials, the decisions and discussions in Latin America shed light on the increasing convergence of national, transnational, and international jurisprudence into a multilayered system. At times, national experiences can help inform international debates; at other times, it is the international discussion that provides fodder for national initiatives.

With regard to amnesty, one way in which to view the evolution traced above is as a balloon: As one part of the balloon is pushed in, some other part pops out to compensate. By prohibiting pre-conviction amnesty, those seeking flexibility will turn to post-conviction conditions of punishment. Whether this change in focus is acceptable depends in part on what is exacted in exchange, and in part on an evaluation of the proper purposes of prosecution and punishment. If prosecution is necessary to establish what happened and who was responsible, provide victims with the opportunity to confront their victimizers in court, establish norms for proper behavior, and inoculate against future denial, then a strict anti-amnesty norm coupled with a flexible punishment policy-even for those most responsible-may be acceptable. In this regard, there is a clear difference between the regional human rights courts and the ICC. The regional courts, led by the Inter-American Court, have grounded the anti-amnesty norm in the rights of victims to judicial process and to the remedies found in Articles 8 and 25 of the American Convention on Human Rights. That grounding would seem to allow creative amnesties so long as the rights of victims are respected. This option represents the apparent direction of the Colombian Constitutional Court as well. This view holds that the important normative aspects of these types of trials are grounded in the information provided, the opportunity for survivors to confront the defendant, and the declaratory power of a judgment in (re)affirming essential social values. 
The ICC and many advocates, in contrast, ground an anti-amnesty norm in the duties of states to prosecute under international criminal law, independently of victims. The underlying normative view here seems to be that prosecution is only an effective deterrent, or a just desert, when it is followed by swift, sure, and harsh punishment. ${ }^{105}$ If that is the starting position, then flexible punishment logically runs the risk of becoming simply the latest incarnation of impunity. M. deGuzman, Harsh Justice for International Crimes?, 39 Y ALE J. INT'L L. 1 (2014). 